\title{
Exceptionally Inert Lanthanide(III) PARACEST MRI Contrast Agents Based on an 18-Membered Macrocyclic Platform ${ }^{* *}$
}

Goretti Castro $^{\mathrm{a}}$, Martín Regueiro-Figueroa ${ }^{\mathrm{b}}$, David Esteban-Gómez ${ }^{\mathrm{b}}$, Rufina Bastida ${ }^{\mathrm{c}}$, Alejandro Macías $^{c}$, Paulo Pérez-Lourido ${ }^{a}$, Carlos Platas-Iglesias ${ }^{\mathrm{b}}$, and Laura Valencia ${ }^{\mathrm{a}}$

${ }^{\text {a }}$ Departamento de Química Inorgánica, Facultad de Ciencias, Universidade de Vigo, As Lagoas, Marcosende 36310 Pontevedra (Spain)

${ }^{\mathrm{b}}$ Grupo QUICOOR, Centro de Investigaciones Científicas Avanzadas (CICA) and Departamento de Química Fundamental, Universidade da Coruña, Campus da Zapateira-Rúa da Fraga 1015008 A Coruña (Spain)

${ }^{\mathrm{c}}$ Departamento de Química Inorgánica, Facultad de Química Universidad de Santiago de Compostela, Avda. de las Ciencias s/n, 15782, Santiago de Compostela (Spain)

Chemistry - A European Journal Volume 21, Issue 51, pages 18662-18670, December 14, 2015 Issue online: 4 December 2015, Version of record online: 5 November 2015, Manuscript Received: 27 July 2015

This is the peer reviewed version of the following article:

Castro, G., Regueiro-Figueroa, M., Esteban-Gómez, D., Bastida, R., Macías, A., Pérez-Lourido, P., PlatasIglesias, C. and Valencia, L. (2015), Exceptionally Inert Lanthanide(III) PARACEST MRI Contrast Agents Based on an 18-Membered Macrocyclic Platform. Chem. Eur. J., 21: 18662-18670.

which has been published in final form at https://doi.org/10.1002/chem.201502937. This article may be used for non-commercial purposes in accordance with Wiley Terms and Conditions for Self-Archiving.

\begin{abstract}
We report a macrocyclic ligand based on a 3,6,10,13-tetraaza-1,8(2,6)-dipyridinacyclotetradecaphane platform containing four hydroxyethyl pendant arms $\left(\mathrm{L}^{1}\right)$ that forms extraordinary inert complexes with $\mathrm{Ln}^{3+}$ ions. The $\left[\mathrm{EuL}^{1}\right]^{3+}$ complex does not undergo dissociation in $1 \mathrm{~m} \mathrm{HCl}$ over a period of months at room temperature. Furthermore, high concentrations of phosphate and $\mathrm{Zn}^{2+}$ ions at room temperature do not provoke metal-complex dissociation. The X-ray crystal structures of six $\operatorname{Ln}^{3+}$ complexes reveal ten coordination of the ligand to the metal ions through the six nitrogen atoms of the macrocycle and the four oxygen atoms of the hydroxyethyl pendant arms. The analysis of the $\mathrm{Yb}^{3+}$ - and $\mathrm{Pr}^{3+}$-induced paramagnetic ${ }^{1} \mathrm{H}$ NMR shifts show that the solid-state structures are retained in aqueous solution. The intensity of the ${ }^{1} \mathrm{H}$ NMR signal of bulk water can be modulated by saturation of the signals of the hydroxy protons of $\mathrm{Pr}^{3+}, \mathrm{Eu}^{3+}$, and $\mathrm{Yb}^{3+}$ complexes following chemical-exchange saturation transfer (CEST). The ability of these complexes to provide large CEST effects at 25 and $37^{\circ} \mathrm{C}$ and $\mathrm{pH} 7.4$ was confirmed by using CEST magnetic resonance imaging experiments.
\end{abstract}

Keywords: CEST; lanthanides; macrocycles; MRI; NMR spectroscopy

\footnotetext{
${ }^{* *}$ MRI=magnetic resonance imaging; PARACEST=paramagnetic chemical-exchange saturation transfer.
} 


\section{Introduction}

Contrast agents (CAs) for magnetic resonance imaging (MRI) used in clinical practice are generally paramagnetic complexes that enhance image contrast by shortening the longitudinal and/or transverse relaxation times of water protons in the vicinity of the paramagnetic probe. ${ }^{[1]}$ Most of the CAs available on the market are $\mathrm{Gd}^{3+}$ complexes that contain a coordinated water molecule that exchanges rapidly with bulk water, thereby imparting an efficient mechanism for shortening of the relaxation times of water in the surrounding tissue. ${ }^{[1,2]}$

In recent years, CAs based on the chemical-exchange saturation transfer (CEST) approach have emerged as an attractive alternative to the classical $\mathrm{Gd}^{3+}$-based agents. ${ }^{[3]} \mathrm{CEST}$ agents require a pool of exchangeable protons under intermediate-to-slow conditions with the bulk water $\left(\mathrm{k}_{\mathrm{ex}} \leq \Delta \omega\right)$. Under these conditions, application of a presaturation pulse at the frequency of the exchangeable protons provokes the transfer of some saturated spins into the water pool, thereby attenuating the signal of bulk water. ${ }^{[3,4]}$

Some paramagnetic ions can induce important shifts of the ${ }^{1} \mathrm{H}$ NMR resonances without provoking extensive line broadening. The PARACEST approach takes advantage of these paramagnetic shifts to increase the chemical-shift difference between the exchanging proton and bulk water $(\Delta \omega)$, which produces beneficial results because: 1) the resonance of the exchanging protons is shifted well away from the bulk water resonance and 2) the exchange rate of the exchangeable protons $\left(k_{e x}\right)$ can be faster while maintaining the slow-to-intermediate exchange regime. ${ }^{[5]}$ Among the different paramagnetic ions both lanthanide ${ }^{[6]}$ and transition-metal ions $\left(\mathrm{Fe}^{2+}, \mathrm{Ni}^{2+} \text {, and } \mathrm{Co}^{2+}\right)^{[5 a, 7]}$ complexed with ligands containing exchangeable protons have been shown to provide a PARACEST effect. Furthermore, some PARACEST agents have also been detected in vivo. ${ }^{[8]}$

Concerning the nature of the exchangeable protons, typically amide ${ }^{[9]}$ or amine ${ }^{[10]} \mathrm{NH}$ protons and the coordinated water molecule in 1,4,7,10-tetraazacyclododecane-1,4,7,10-tetraacetic acid (DOTA)-tetraamide $\mathrm{Ln}^{3+}$ complexes $^{[11]}$ have been exploited as exchangeable pools. The alcohol $\mathrm{OH}$ groups of hydroxyethyl pendant arms have been also employed as exchangeable protons that provide a PARACEST effect. ${ }^{[12]}$ In the particular case of $\mathrm{Ln}^{3+}$ ions, DOTA derivatives in which the acetate groups are replaced by hydroxyethyl pendants have been tested as potential PARACEST agents. However, the exchange of hydroxy protons was found to be too fast to provide a CEST effect in water because the signal of the $\mathrm{OH}$ protons is not highly shifted with respect to the signal of bulk water. ${ }^{[13]} \mathrm{The} \mathrm{Ce}^{3+}$ and $\mathrm{Eu}^{3+}$ complexes of S-THP (Scheme 1) were shown later to provide sizeable CEST effects at a close-to-neutral $\mathrm{pH}$ value in spite of the relatively small shift of the signal due to the $\mathrm{OH}$ protons. ${ }^{[14]}$ Furthermore, the $\mathrm{Eu}^{3+}$ and $\mathrm{Yb}^{3+}$ complexes of HP-DO3A (Scheme 1) were reported to provide PARACEST effects both in vitro and in vivo. ${ }^{[15]}$

An important condition that must be fulfilled by a $\mathrm{Ln}^{3+}$ - based CA is to possess a high kinetic inertness with respect to metal-ion dissociation because the free $\mathrm{Ln}^{3+}$ ions are toxic. ${ }^{[16]} \mathrm{In}$ this respect, $\mathrm{Ln}^{3+}$ complexes derived from 1,4,7,10-tetraazacyclododecane (cyclen) containing four pendant arms, such as DOTAM (Scheme 1) and HP-DO3A, have been shown to be complexes with exceptionally high kinetic inertness. ${ }^{[17]}$ Thus, $\mathrm{Ln}^{3+}$-DOTAM derivatives with different substituents at the amide group have been intensively investigated as PARACEST agents.

Herein, we report a new class of $\mathrm{Ln}^{3+}$-based PARACEST agent derived from the macrocyclic ligand $\mathrm{L}^{1}$, which is based on a 18-membered macrocycle containing two pyridine head units and four hydroxyethyl groups (Scheme 1). The corresponding $\mathrm{Ln}^{3+}$ complexes are extremely inert, whereas the $\mathrm{Pr}^{3+}, \mathrm{Eu}^{3+}$, and $\mathrm{Yb}^{3+}$ derivatives provide remarkable contrast by means of the CEST mechanism. A full structural characterization of the complexes is also presented. 


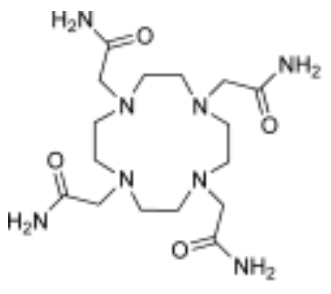

DOTAM

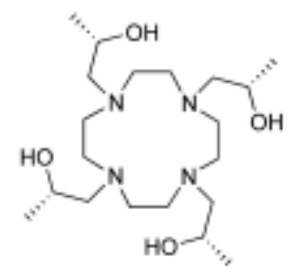

S-THP

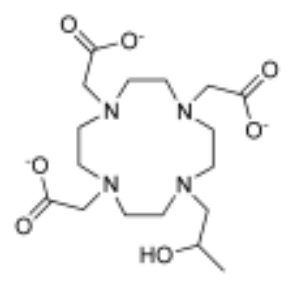

HP-DO3A

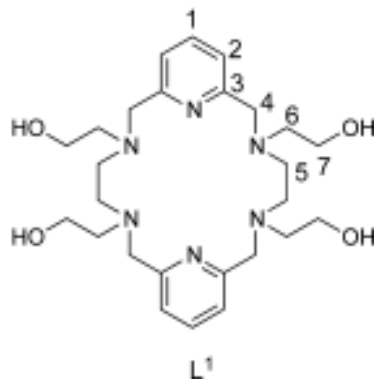

Scheme 1. Ligands discussed herein and the numbering scheme used for the NMR-spectral assignment of complexes of $\mathrm{L}^{1}$.

\section{Results and Discussion}

\section{Synthesis}

The synthesis of the 3,6,10,13-tetraaza-1,8(2,6)-dipyridinacyclotetradecaphane precursor was achieved by following the procedure reported by Jackels and co-workers, which involves the condensation of pyridine2,6-dicarbaldehyde and ethylenediamine with $\mathrm{BaCl}_{2}$ as a template, followed by the reduction of the resulting Schiff base with $\mathrm{NaBH}_{4} \cdot{ }^{[18]}$ Ligand $\mathrm{L}^{1}$ was subsequently obtained in good yield by reaction of the parent macrocycle with ethylene oxide in methanol (see Figure $\mathrm{S} 1$ in the Supporting Information). Compounds with the formula $\left[\mathrm{Ln}\left(\mathrm{L}^{1}\right)\right]\left(\mathrm{NO}_{3}\right)_{3} \cdot \mathrm{x} \mathrm{H}_{2} \mathrm{O}(\mathrm{x}=3-6$; $\mathrm{Ln}=\mathrm{La}-\mathrm{Lu}$, except for Pm) were obtained in good yields $(50$ $80 \%$ ) by direct reaction between the ligand and the appropriate hydrated lanthanide nitrate in methanol.

\section{$\underline{\mathrm{X} \text {-ray structures }}$}

The crystal structures of compounds $\left[\mathrm{LnL}^{1}\right]\left(\mathrm{NO}_{3}\right)_{3} \cdot \mathrm{x} \mathrm{H}_{2} \mathrm{O}(\mathrm{x}=3-6$; $\mathrm{Ln}=\mathrm{La}, \mathrm{Pr}, \mathrm{Nd}, \mathrm{Sm}, \mathrm{Yb}$, or Lu) were determined by single-crystal $\mathrm{X}$-ray diffraction measurements. Crystals were obtained by slow evaporation of aqueous solutions of the complexes. Views of the structures of the representative $\left[\mathrm{LaL}^{1}\right]^{3+}$ and $\left[\mathrm{LuL}^{1}\right]^{3+}$ complexes are shown in Figures 1 and 2, whereas the bond lengths of the metal-coordination environments are given in Table 1. Crystal data of all the compounds are collected in Table S1 (see the Supporting Information).

Compounds $\left[\mathrm{LaL}^{1}\right]\left(\mathrm{NO}_{3}\right)_{3} \cdot 2 \mathrm{H}_{2} \mathrm{O},\left[\mathrm{PrL}^{1}\right]\left(\mathrm{NO}_{3}\right)_{3} \cdot 4 \mathrm{H}_{2} \mathrm{O},\left[\mathrm{NdL}^{1}\right]\left(\mathrm{NO}_{3}\right)_{3} \cdot 6 \mathrm{H}_{2} \mathrm{O}$, and $\left[\mathrm{SmL}^{1}\right]\left(\mathrm{NO}_{3}\right)_{3} \cdot 5 \mathrm{H}_{2} \mathrm{O}$ are isostructural and crystallize in the centrosymmetric $\mathrm{C}_{2} / \mathrm{c}$ monoclinic space group. The asymmetric units contain half a $\left[\mathrm{LnL}^{1}\right]^{3+}$ ion, one and a half disordered independent nitrate ions, and some water molecules of crystallization. Complexes $\left[\mathrm{YbL}^{1}\right]\left(\mathrm{NO}_{3}\right)_{3} \cdot 6 \mathrm{H}_{2} \mathrm{O}$ and $\left[\mathrm{LuL}^{1}\right]\left(\mathrm{NO}_{3}\right)_{3} \cdot 6 \mathrm{H}_{2} \mathrm{O}$ are also isostructural and crystallize in the non-centrosymmetric $\mathrm{C}_{2}$ monoclinic space group. In these cases, the asymmetric units consist of two half $\left[\mathrm{LnL}^{1}\right]^{3+}$ ions, three independent nitrate ions, and different water molecules of crystallization. 


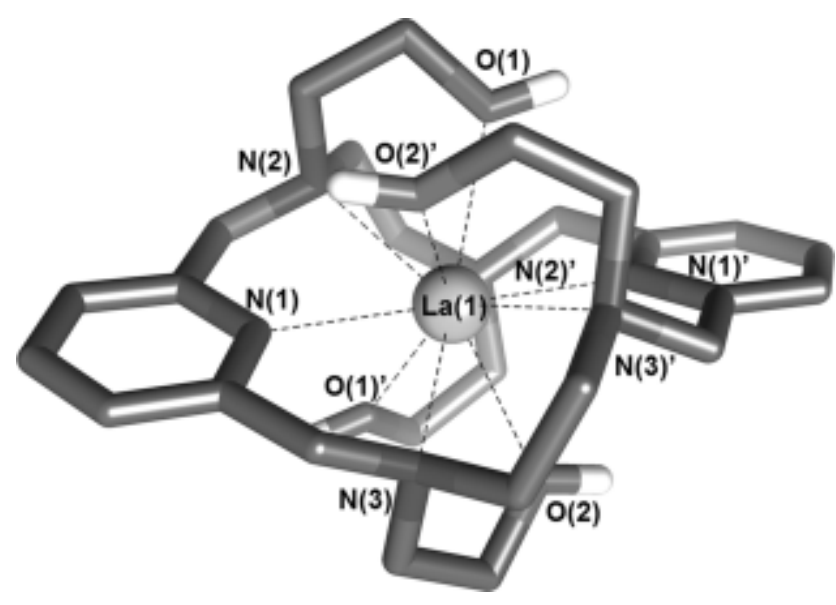

Figure 1. View of the complex cation present in crystals of $\left[\mathrm{LaL}^{1}\right]\left(\mathrm{NO}_{3}\right)_{3} \cdot 2 \mathrm{H}_{2} \mathrm{O}$. The water molecules, anions, and hydrogen atoms (except those of the hydroxy groups) have been omitted for simplicity.
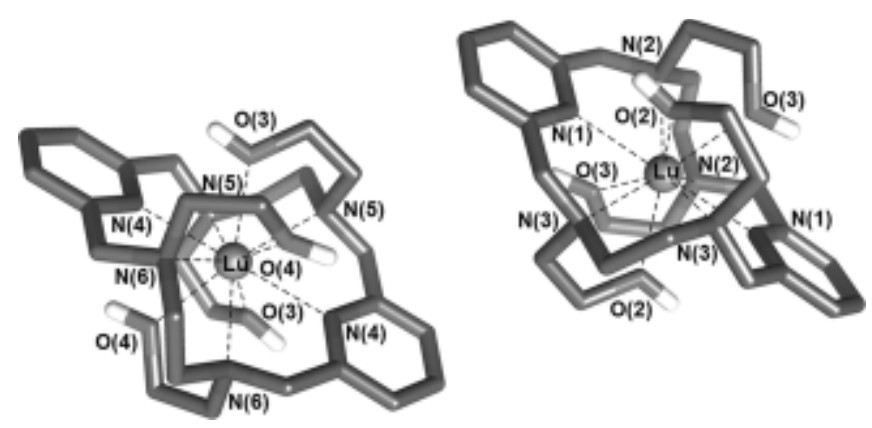

Figure 2. View of the two complex cations present in crystals of $\left[\mathrm{LuL}^{1}\right]\left(\mathrm{NO}_{3}\right)_{3} \cdot 6 \mathrm{H}_{2} \mathrm{O}$. The water molecules, anions, and hydrogen atoms (except those of the hydroxy groups) have been omitted for simplicity.

The structures of all the $\left[\mathrm{LnL}^{1}\right]^{3+}$ ions are similar and show the metal ion within the macrocyclic cavity coordinated to the ten donor atoms of the ligand, which consist of the six nitrogen atoms of the macrocycle and the four oxygen atoms of the hydroxy groups. The conformation of the macrocyclic ligand is similar to that found for lanthanide complexes derived from the same macrocyclic platform functionalized with four acetate ${ }^{[19]}$ methylenephosphonate,${ }^{[20]} 2$-methylpyridine, ${ }^{[21]}$ or acetohydrazide ${ }^{[22]}$ pendant arms, which were shown to form ten-coordinated lanthanide(III) complexes. In the case of the complexes with the ligandcontaining acetate pendant arms, a decrease of the coordination number from ten to nine was observed for the smallest $\mathrm{Ln}^{3+}$ ions because one of the oxygen atoms of a pendant arm remains uncoordinated. ${ }^{[19]}$ In the other cases, the crystal structures of the $\left[\mathrm{LnL}^{1}\right]^{3+}$ complexes indicate that these complexes remain tencoordinated along the whole lanthanide series from the $\mathrm{La}^{3+}$ to the $\mathrm{Lu}^{3+}$ ions.

The four hydroxyethyl pendant groups are alternatively placed above and below the average macrocyclic plane. The $\mathrm{N}(1)-\operatorname{Ln}(1)-\mathrm{N}(1)$ angles, which involve the pyridine nitrogen atoms, are close to $180^{\circ}(178.5-$ $\left.179.9^{\circ}\right)$, which is often observed when derivatives of $\mathrm{L}^{1}$ coordinate large metal ions. ${ }^{[18-22]}$ However, the two pyridyl units are twisted with respect to each other, so that the least-squares planes intersect at angles that range from 14.6 to $20.2^{\circ}$ (see Table S2 in the Supporting Information). The two five-membered chelate rings formed upon coordination of the ethylenediamine units adopt identical conformations that can be described 
as $\lambda \lambda$ or $\delta \delta$, as crystals contain the two enantiomeric forms of the complexes (racemate). The two enantiomers are centrosymmetrically related in those compounds that crystallize in the $\mathrm{C}_{2} / \mathrm{c}$ space group, whereas the two half-complex units present in the asymmetric unit of the crystals belonging to the $\mathrm{C}_{2}$ monoclinic space group generate the $\lambda \lambda$ and $\delta \delta$ enantiomers.

Table 1. Bond lengths $[\AA]$ of the metal-coordination environments observed in the X-ray structures of the $\left[\operatorname{Ln}\left(\mathrm{L}^{1}\right)\right]^{3+}$ complexes.

\begin{tabular}{|c|c|c|c|c|c|c|}
\hline & La & Pr & Nd & Sm & $\mathbf{Y b}$ & Lu \\
\hline $\operatorname{Ln}(1)-\mathrm{N}(1)$ & $2.617(7)$ & $2.591(6)$ & $2.600(5)$ & $2.582(6)$ & 2.539(3) & $2.540(3)$ \\
\hline $\operatorname{Ln}(1)-\mathrm{N}(2)$ & $2.709(7)$ & $2.695(5)$ & $2.675(5)$ & $2.674(6)$ & 2.644(3) & $2.645(5)$ \\
\hline $\operatorname{Ln}(1)-\mathrm{N}(3)$ & $2.704(7)$ & $2.700(6)$ & $2.684(5)$ & $2.673(6)$ & $2.620(3)$ & $2.618(4)$ \\
\hline $\operatorname{Ln}(1)-\mathrm{O}(1)$ & 2.611(5) & $2.544(5)$ & $2.518(4)$ & $2.506(5)$ & 2.419(3) & $2.426(4)$ \\
\hline $\operatorname{Ln}(1)-\mathrm{O}(2)$ & $2.583(4)$ & $2.568(4)$ & $2.533(4)$ & $2.522(5)$ & 2.411(3) & $2.407(3)$ \\
\hline $\operatorname{Ln}(2)-\mathrm{N}(4)$ & & & & & $2.557(3)$ & $2.556(4)$ \\
\hline $\operatorname{Ln}(2)-\mathrm{N}(5)$ & & & & & $2.621(3)$ & $2.630(4)$ \\
\hline $\operatorname{Ln}(2)-\mathrm{N}(6)$ & & & & & 2.633(3) & $2.630(4)$ \\
\hline $\operatorname{Ln}(2)-O(3)$ & & & & & 2.419(3) & $2.418(3)$ \\
\hline $\operatorname{Ln}(2)-\mathrm{O}(4)$ & & & & & $2.429(3)$ & $2.430(3)$ \\
\hline
\end{tabular}

The Ln-O bond lengths are generally shorter than the $\mathrm{Ln}-\mathrm{N}$ bonds, whereas the $\mathrm{Ln}-\mathrm{N}_{\text {pyridine }}$ distances are shorter than $\mathrm{Ln}-\mathrm{N}_{\text {amine }}$ counterparts, which was observed for $\mathrm{Ln}^{3+}$ complexes with related macrocyclic ligands. ${ }^{[19-22]}$ In general, the bond lengths decrease on proceeding to the right across the lanthanide series, as expected due to the lanthanide contraction. ${ }^{[23]}$

The coordination polyhedra around the $\mathrm{Ln}^{3+}$ ions can be described as distorted bicapped square antiprisms (Figure 3). One of the square planes is comprised of $\mathrm{N}(2), \mathrm{N}(3), \mathrm{O}(1)^{\prime}$, and $\mathrm{O}(2)^{\prime}$, whereas the second square face is delineated by $\mathrm{N}(2)^{\prime}, \mathrm{N}(3)^{\prime}, \mathrm{O}(1)$, and $\mathrm{O}(2)$. The values of the root-mean square (rms) of these planes oscillate between 0.12 and $0.17 \AA$ for $\left[\mathrm{LuL}^{1}\right]^{3+}$ and $\left[\mathrm{LaL}^{1}\right]^{3+}$, respectively. The mean twist angles of the two square faces $\left(40.7-41.5^{\circ}\right)$ are close to the ideal value expected for a square antiprism $\left(45^{\circ}\right)$. The pyridine nitrogen atoms $\mathrm{N}(1)$ and $\mathrm{N}(1)^{\prime}$ each cap one of the square planes at distances that vary from 1.60 to $1.53 \AA$ for $\left[\mathrm{LaL}^{1}\right]^{3+}$ and $\left[\mathrm{LuL}^{1}\right]^{3+}$, respectively. The square-planar faces of the polyhedron are virtually parallel and the least-squares planes intersect at angles that range from 0.08 to $0.31^{\circ}$ (see Table S2 in the Supporting Information). 


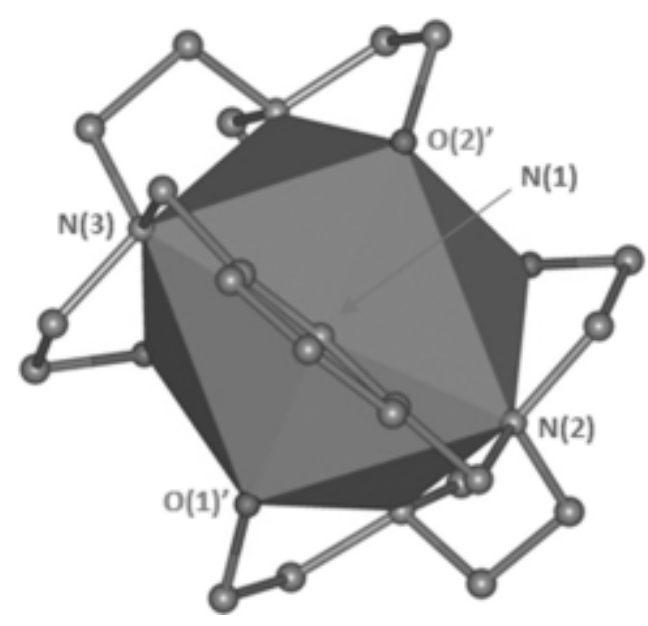

Figure 3. The bicapped square antiprismatic coordination polyhedron around the metal ion in the $\left[\mathrm{YbL}^{1}\right]^{3+}$ complex.

\section{$\underline{\text { Solution structure }}$}

The absorption spectra of the $\left[\mathrm{EuL}^{1}\right]^{3+}$ complex presents an absorption band with a maximum at $\lambda=269 \mathrm{~nm}$ attributed to the pyridyl chromophore. ${ }^{[24]}$ The emission spectrum recorded under excitation through this band presents the expected ${ }^{5} \mathrm{D}_{0} \rightarrow{ }^{7} \mathrm{~F}_{J}(J=0-4)$ transitions characteristic of the $\mathrm{Eu}^{3+}$ ion (see Figure $\mathrm{S} 2$ in the Supporting Information). The excitation spectrum is virtually superimposable on the absorption spectra, thus indicating lanthanide sensitization through the antenna effect. ${ }^{[25]}$ The lifetimes of the $\mathrm{Eu}^{3+}{ }^{5} \mathrm{D}_{\mathrm{o}}$ excited state measured in solutions of $\mathrm{H}_{2} \mathrm{O}$ and $\mathrm{D}_{2} \mathrm{O}$ of the complex $\left(10^{-5}{ }_{\mathrm{m}}\right)$ are $0.38(2)$ and 1.37(2) ms, respectively. These values were used to estimate the number of $\mathrm{OH}$ oscillators coordinated to the metal ion by using the relationship proposed by Beeby et al. ${ }^{[26]}$ This equation provides the number of $\mathrm{OH}$ oscillators coordinated to the metal ion of 4.0, which is in nice agreement with a ten-coordinate complex in which the coordination sphere is filled by the six nitrogen donor atoms of the macrocycle and the four hydroxy $\mathrm{OH}$ groups.

The ${ }^{1} \mathrm{H}$ NMR spectrum of the diamagnetic $\mathrm{Lu}^{3+}$ complex recorded in solution with $\mathrm{D}_{2} \mathrm{O}$ presents ten signals, thus pointing to a $\mathrm{D}_{2}$ symmetry of the complex in solution. This indication is confirmed by the ${ }^{13} \mathrm{C}$ NMR spectrum, which displays seven signals for the 26 carbon nuclei of the ligand skeleton (see Figure S3 and Table S3 in the Supporting Information). The proton NMR spectra of the paramagnetic complexes of $\operatorname{Pr}^{3+}$, $\mathrm{Eu}^{3+}$, and $\mathrm{Yb}^{3+}$ recorded in $\mathrm{D}_{2} \mathrm{O}$ also present the expected ten paramagnetically shifted signals. In the particular case of the $\mathrm{Yb}^{3+}$ complex, the paramagnetic signals are spread from approximately $\delta=+70$ to -34 ppm at $25^{\circ} \mathrm{C}$ (see Figure 4 and Figure S4 in the Supporting Information). The paramagnetic ${ }^{1} \mathrm{H}$ NMR shifts of $\mathrm{Yb}^{3+}$ complexes are dominated by the pseudocontact contribution, which is the result of the dipolar coupling between the magnetic moments of the unpaired electrons and the observed nucleus. ${ }^{[27]}$ The pseudocontact shift can be approximated by using Equation (1): ${ }^{[27,28]}$

$$
\delta_{\mathrm{ij}}^{\mathrm{dip}}=\left(\chi_{\mathrm{zz}}-\frac{1}{3} \operatorname{Tr} \chi\right)\left(\frac{3 z^{2}-r^{2}}{r^{5}}\right)+\left(\chi_{\mathrm{xx}}-\chi_{\mathrm{yy}}\right)\left(\frac{x^{2}-y^{2}}{r^{5}}\right)
$$

where $\chi_{z z}-1 / 3\left(\chi_{x x}+\chi_{y y}+\chi_{z z}\right)$ and $\chi_{x x}-\chi_{y y}$ represent the axial and rhombic anisotropies of the magneticsusceptibility tensor $(\chi) ; x, y$, and $z$ are the Cartesian coordinates of the observed nucleus with the lanthanide at the origin; and $r$ is the distance between the observed nucleus and the paramagnetic ion. ${ }^{[28]}$ It has been shown that the paramagnetic shifts of $\mathrm{Yb}^{3+}$ complexes can be accurately approximated by using this 
expression, which requires approximating the structure in solution of the complex. ${ }^{[29,30]}$ Following our previous studies, ${ }^{[29,30]}$ we used the molecular structure of the $\left[\mathrm{YbL}^{1}\right]^{3+}$ complex obtained by DFT calculations in aqueous solution at the TPSSh/LCRECP/6-31G(d,p) level (see Figure S5 in the Supporting Information). The optimized structure presents a nearly undistorted $D_{2}$ symmetry with $\mathrm{Yb}-\mathrm{N}_{\mathrm{py}}=2.552, \mathrm{Yb}-$ $\mathrm{N}_{\text {amine }}=2.655$, and $\mathrm{Yb}-\mathrm{O}=2.455 \AA$. These distances are in very good agreement with the experimental values observed in the solid state (see Table 1 and Table S4 in the Supporting Information).

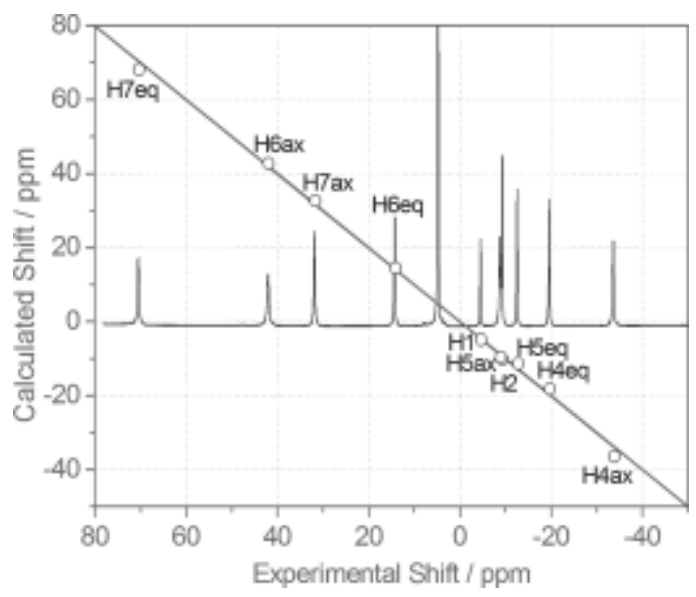

Figure 4. ${ }^{1} \mathrm{H}$ NMR spectrum of the $\left[\mathrm{YbL}^{1}\right]^{3+}$ complex recorded in $\mathrm{D}_{2} \mathrm{O}$ at $25^{\circ} \mathrm{C}(\mathrm{pH} 7.0,300 \mathrm{MHz})$ and plot of the observed experimental shifts versus those calculated by using Equation (1). The solid line represents a perfect agreement between the experimental and calculated data.

The agreement between the experimental shifts of the $\left[\mathrm{YbL}^{1}\right]^{3+}$ complex and those values calculated by using Equation (1) is excellent (see Figure 4 and Table S3 in the Supporting Information), with deviations between the experimental and calculated data of $<2.6 \mathrm{ppm}$. The agreement factor $(\mathrm{AF} j)$ of $0.044^{[31]}$ is similar to those of other $\mathrm{Yb}^{3+}$ complexes analyzed by using this methodology. ${ }^{[29,30,32]}$ This outcome confirms that the $\left[\mathrm{YbL}^{1}\right]^{3+}$ complex presents a ten-coordinate structure in solution similar to that observed in the solid state. A similar analysis performed for the $\mathrm{Pr}^{3+}$ complex (see Figures S6 and S7 and Table S3 in the Supporting Information) also provides a satisfactory agreement between the experimental and calculated data (deviations of $<3.0 \mathrm{ppm}, \mathrm{AFj}=0.112$ ) considering that the contact shifts are expected to be significant for this ion. ${ }^{[32,33]}$ These results indicate that the $\left[\mathrm{LnL}^{1}\right]^{3+}$ complexes form ten-coordinate complexes all along the lanthanide series from $\mathrm{Pr}^{3+}$ to $\mathrm{Lu}^{3+}$, in line with the structures observed in the solid state.

\section{CEST studies}

The NMR spectra of the $\left[\mathrm{PrL}^{1}\right]^{3+},\left[\mathrm{EuL}^{1}\right]^{3+}$, and $\left[\mathrm{YbL}^{1}\right]^{3+}$ complexes were recorded in $\mathrm{H}_{2} \mathrm{O}$ at $\mathrm{pH}$ 7.0. A comparison of the spectra recorded in $\mathrm{D}_{2} \mathrm{O}$ and $\mathrm{H}_{2} \mathrm{O}$ allowed us to establish the chemical shifts of the hydroxy protons, which present shifts of $\Delta \delta=-25.2,+21.6$, and $+42.0 \mathrm{ppm}\left(\left[\mathrm{PrL}^{1}\right]^{3+},\left[\mathrm{EuL}^{1}\right]^{3+} \text {, and } \mathrm{YbL}^{1}\right]^{3+}$, respectively) with respect to the signal of bulk water at $25^{\circ} \mathrm{C}$ (Figure 5). The different signs of the chemical shifts observed for the $\mathrm{OH}$ protons is obviously related to the different signs of the Bleaney constants, ${ }^{[34]}$ which govern the pseudocontact contributions and are negative in the case of the $\operatorname{Pr}^{3+}$ ion and positive for the $\mathrm{Eu}^{3+}$ and $\mathrm{Yb}^{3+}$ ions. ${ }^{[27 \mathrm{a}]}$ The protons of $\mathrm{OH}$ groups are only two bonds away from the paramagnetic center; therefore, it is likely that the contact contribution to the paramagnetic shift is significant. Contact contributions are proportional to the spin-expectation values $\left\langle\mathrm{S}_{\mathrm{Z}}\right\rangle,{ }^{[35]}$ which as the corresponding Bleaney constants are negative for the $\operatorname{Pr}^{3+}$ ion and positive for the $\mathrm{Eu}^{3+}$ and $\mathrm{Yb}^{3+}$ ions. ${ }^{[27 \mathrm{a}]}$ The chemical shift of the $\mathrm{OH}$ protons observed for the $\left[\mathrm{EuL}^{1}\right]^{3+}$ complex is considerably larger than that reported for $\mathrm{Eu}-S-\mathrm{THP}^{3+}$ $(\Delta \delta=4.8 \mathrm{ppm})$ and related systems. ${ }^{[14]}$ 

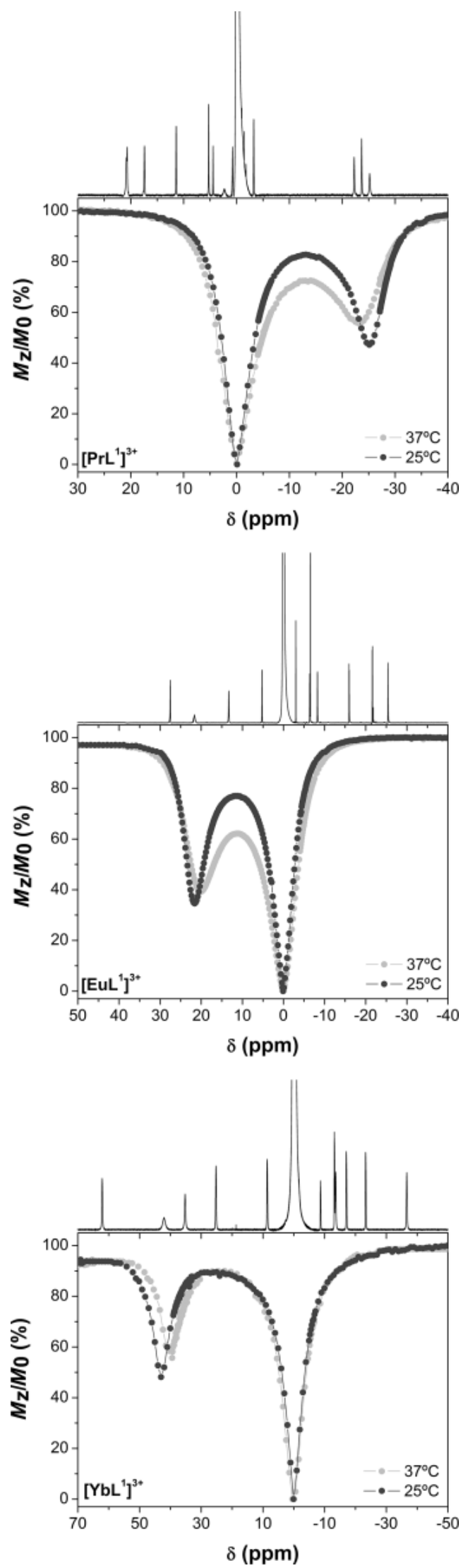

Figure 5. ${ }^{1} \mathrm{H}$ NMR spectra $(7.05 \mathrm{~T})$ of the $\left[\mathrm{PrL}^{1}\right]^{3+},\left[\mathrm{EuL}^{1}\right]^{3+}$, and $\left[\mathrm{YbL}^{1}\right]^{3+}$ complexes at $25^{\circ} \mathrm{C}$ and CEST spectra recorded at 25 and $37^{\circ} \mathrm{C}\left(20 \mathrm{~mm}\right.$ HEPES, $\left.\mathrm{pH} 7.4,0.15 \mathrm{M} \mathrm{NaCl}, 300 \mathrm{MHz}, B_{1}=6.9 \mu \mathrm{T}, 10 \mathrm{~s}\right)$. The huge bulk-water signals were truncated for better visualization. Note the slight shift of the resonance of hydroxy protons with respect to bulk water upon increasing temperature. 
A CEST spectrum is a plot of intensity of the water-proton resonance $\left(M_{\mathrm{z}}\right)$ normalized to that of the water signal in the absence of the presaturation pulse $\left(M_{0}\right)$ as a function of the frequency of the presaturation pulse. In line with previous studies, ${ }^{[14]}$ preliminary CEST experiments performed on a solution of the $\left[\mathrm{YbL}^{1}\right]^{3+}$ at pH 6.0 and 7.0 reflected a significant impact of the pH value in the observed CEST effect (see Figure S8 in the Supporting Information). Thus, subsequent CEST studies were carried out in buffered aqueous solutions (i.e., $20 \mathrm{~m}_{\mathrm{m}}$ 4-(2-hydroxyethyl)-1-piperazineethanesulfonic acid (HEPES)). The CEST spectra recorded for the $\left[\mathrm{PrL}^{1}\right]^{3+}$ complex at $25^{\circ} \mathrm{C}$ (presaturation period $=10 \mathrm{~s}$, presaturation power $B_{1}=6.9 \mu \mathrm{T}, 30 \mathrm{mM}$ ) shows a CEST peak at the position of the $\mathrm{OH}$ protons (ca. $53 \%$ ), which is slightly decreased (to ca. $45 \%$ ) upon increasing the temperature to $37^{\circ} \mathrm{C}$ (Figure 5). Similar CEST effects are observed for the $\left[\mathrm{YbL}^{1}\right]^{3+}$ complex under identical conditions (ca. 52 and $45 \%$ at 25 and $37{ }^{\circ} \mathrm{C}$, respectively). A somewhat stronger CEST effect was observed for the [EuL1]3+ complex at both 25 and $37^{\circ} \mathrm{C}$ (ca. 66 and $61 \%$, respectively).

The CEST effect observed for a particular complex depends upon a large number of variables, and thus a direct comparison of the performance of the different systems is not straightforward. However, a simple inspection of the CEST effects reported for $\mathrm{Ln}^{3+}$ complexes of DOTA-tetraamides suggests that the $\left[\mathrm{LnL}^{1}\right]^{3+}$ complexes provide comparable results. ${ }^{[9,11]}$

The exchange rates of the $\mathrm{OH}$ protons were assessed by using the omega-plot method reported by Sherry and co-workers. ${ }^{[36]}$ This method relies on the acquisition of different CEST spectra by using different presaturation powers. Assuming that the exchange rate of the concerned protons is fast with respect to the relaxation rates of the two proton pools, the Equation (2) holds:

$$
\frac{M_{\mathrm{z}}}{M_{0}-M_{\mathrm{z}}}=\frac{55.5}{c} k_{\mathrm{b}} R_{1}^{\mathrm{a}}\left(\frac{1}{k_{b}^{2}}+\frac{1}{\omega_{1}^{2}}\right)
$$

where $c$ is the concentration of exchangeable protons, $k_{\mathrm{b}}$ is the exchange rate of exchangeable protons, $R_{1}{ }^{\mathrm{a}}$ is the relaxation rate of bulk water protons, and $\omega_{1}$ is the amplitude of the radiofrequency magnetic-field strength $\left(B_{1}\right)$ in radians s ${ }^{-1}$. Thus, a plot of $M_{\mathrm{z}} /\left(M_{0}-M_{\mathrm{z}}\right)$ versus $1 / \omega_{1}{ }^{2}$ should be linear with an intercept $/ y$ slope ratio of $1 / k_{\mathrm{b}}{ }^{2}$. The omega plots obtained at $25^{\circ} \mathrm{C}$ for the $\left[\mathrm{LnL}^{1}\right]^{3+}$ complexes $(\mathrm{Ln}=\mathrm{Pr}, \mathrm{Eu}$, or $\mathrm{Yb})$ indeed show linear trends $\left(R^{2}>0.999\right.$; see Figure S12 in the Supporting Information) that provided exchange rates of the hydroxy protons of $3.5 \times 10^{3}, 2.8 \times 10^{3}$, and $4.3 \times 10^{3} \mathrm{~s}^{-1}\left(\mathrm{Pr}^{3+}, \mathrm{Eu}^{3+}\right.$, and $\mathrm{Yb}^{3+}$, respectively). It has been shown that the exchange rates of hydroxy protons increase significantly upon increasing the $\mathrm{pH}$ value, which is typical of base-catalyzed exchange processes. ${ }^{[14 b]}$ Thus, the exchange rates of hydroxy protons are expected to increase as their acidity increases. The increased exchange rate observed across the lanthanide series from $\mathrm{Eu}^{3+}$ to $\mathrm{Yb}^{3+}$ is likely related to an increased acidity of the $\mathrm{OH}$ protons, which can be explained by an increased polarization of the $\mathrm{O}-\mathrm{H}$ bonds associated with the increased charge density of the metal ion. However, the exchange rate determined for the $\mathrm{Pr}^{3+}$ ion is unexpectedly faster than that obtained for the $\mathrm{Eu}^{3+}$ complex.

The CEST effects observed for the complexes of $\mathrm{L}^{1}$ were further investigated by performing CEST imaging experiments at $11.75 \mathrm{~T}$ on $2 \mathrm{~mm}_{\mathrm{M}} 8 \mathrm{~mm}$, and $15 \mathrm{~mm}$ aqueous solutions of the $\mathrm{Eu}^{3+}$ and $\mathrm{Yb}^{3+}$ complexes $(0.15 \mathrm{M}$ $\mathrm{NaCl}, 20 \mathrm{mм}$ (3-( $N$-morpholino)propanesulfonic acid) MOPS buffer, $\mathrm{pH} 7.4,37^{\circ} \mathrm{C}$; Figure 6). Both complexes provide sizeable CEST contrast at a concentration of $8 \mathrm{~mm}$, which further improves when the concentration is increased to $15 \mathrm{~mm}$. In line with the CEST spectra shown in Figure 5, the $\mathrm{Eu}^{3+}$ complex provides CEST contrast upon irradiation at $\delta=+19.3 \mathrm{ppm}$, whereas no effect is observed with presaturation at $\delta=+38.8 \mathrm{ppm}$. The CEST response is reversed in the case of the $\mathrm{Yb}^{3+}$ complex. 


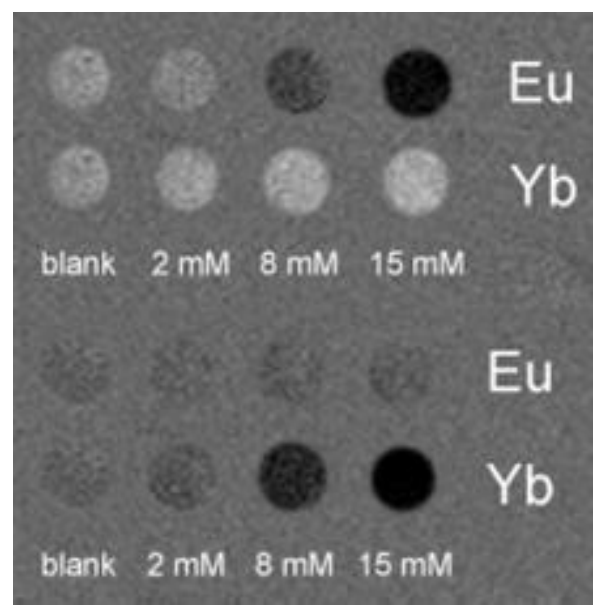

Figure 6. CEST-difference images of the $\left[\mathrm{EuL}^{1}\right]^{3+}$ and $\left[\mathrm{YbL}^{1}\right]^{3+}$ complexes acquired at $11.75 \mathrm{~T}(0.15 \mathrm{M} \mathrm{NaCl}, 20 \mathrm{~mm}$ MOPS buffer, $\mathrm{pH} 7.4,37^{\circ} \mathrm{C}$, irradiation time $=3 \mathrm{~s}, B_{1}=350 \mathrm{~Hz}$ at $\delta=19.3$ (top) and $38.8 \mathrm{ppm}$ (bottom)).

\section{Assessment of the kinetic inertness}

Lanthanide(III) complexes for application in MRI should be inert enough to prevent the release of the toxic metal ion in vivo. ${ }^{[16]}$ Thus, a series of experiments was designed to assess the inertness of the $\left[\mathrm{EuL}^{1}\right]^{3+}$ complex with respect to dissociation. The absorption spectrum of $\mathrm{L}^{1}$ recorded at $\mathrm{pH} 7.0$ displays a maximum at $\lambda=264.5 \mathrm{~nm}\left(\varepsilon \approx 7750 \mathrm{M}^{-1} \mathrm{~cm}^{-1}\right)$, which is blueshifted with respect to that of the $\left[\mathrm{EuL}^{1}\right]^{3+}$ complex and slightly more intense $\left(\lambda_{\max }=269 \mathrm{~nm} ; \varepsilon \approx 7250 \mathrm{~m}^{-1} \mathrm{~cm}^{-1}\right)$. Thus, the absorption spectra of the ligand and complex are significantly different, which allows monitoring the dissociation of the complex by using UV/Vis spectroscopic analysis (see Figures S13 and S14 in the Supporting Information). The absorption spectrum of a solution of the complex of $9.6 \times 10^{-4} \mathrm{M}$ and at $25^{\circ} \mathrm{C}$ remains unchanged over a period of one week upon the addition of an excess of competing biologically relevant anions (70-fold excess of $\mathrm{H}_{2} \mathrm{PO}_{4}{ }^{-} / \mathrm{HPO}_{4}{ }^{2-}$ ions at $\mathrm{pH} 7.0$ or 55 -fold excess of $\mathrm{HCO}_{3}{ }^{-}$ions at $\mathrm{pH}$ 7.0), competing cations (30-fold excess of $\mathrm{Zn}^{2+}$ ions at $\mathrm{pH}$ 5.4), or competing ligands (78-fold excess of ethylenediaminetetraacetate (edta ${ }^{4-}$ ) ions at $\mathrm{pH}$ 7.0). The absence of dissociation in the presence of $\mathrm{H}_{2} \mathrm{PO}_{4}{ }^{-} / \mathrm{HPO}_{4}{ }^{2-}$, which forms insoluble $\mathrm{Eu}\left(\mathrm{PO}_{4}\right)$, is particularly relevant and has been shown to be rather efficient at promoting the dissociation of nonmacrocyclic $\mathrm{Gd}^{3+}$-based contrast agents ${ }^{[37]}$ and $\mathrm{Gd}^{3+}$ complexes with cyclen-based ligands. ${ }^{[38]}$

Acid-catalyzed dissociation represents the main dissociation pathway of $\mathrm{Ln}^{3+}$ complexes with macrocyclic ligands. ${ }^{[16]}$ Therefore, we investigated the kinetic inertness of the $\left[\mathrm{EuL}^{1}\right]^{3+}$ complex in rather concentrated acid solution ( $1 \mathrm{~m} \mathrm{HCl}$ ) by using ${ }^{1} \mathrm{H}$ NMR spectroscopy (Figure 7). The ${ }^{1} \mathrm{H}$ NMR spectrum recorded immediately after the dissolution of the complex shows the expected 11 signals (including the resonance due to the hydroxy $\mathrm{OH}$ protons), whereas no signals due to diamagnetic species could be detected. The spectrum remained unchanged for a period of at least two months. Thus, the complex does not undergo significant dissociation under these rather harsh conditions for prolonged times. Indeed, the $\mathrm{Eu}^{3+}$ complex of DOTA, which is considered to be very inert, presents a lifetime of 13.8 hours under these conditions. ${ }^{[39]}$ The even more inert $[\mathrm{Eu}(\mathrm{DTMA})]^{3+}$ complex presents a lifetime of approximately 11 days in $1 \mathrm{~m} \mathrm{HCl}$, as estimated from the values of the rate constants that characterize the proton-assisted dissociation mechanism. ${ }^{[16 \mathrm{~b}]}$

\section{Conclusion}

The present contribution has shown that an 18-membered macrocycle functionalized with adequate pendant arms provides very inert $\mathrm{Ln}^{3+}$ complexes in aqueous solution. This finding is certainly unexpected 
considering that ligands based on 12-membered macrocycles, such as DOTA derivatives, have long been considered to provide an ideal-size match with $\mathrm{Ln}^{3+}$ ions, which explains the observed high thermodynamic stabilities and kinetic inertness. The detailed structural study presented herein shows that the $\mathrm{Ln}^{3+}$ ions are ten-coordinated by the ligand, which wraps around the metal ion and provides excellent shielding from the environment both in the solid state and in solution. This compact structure, with the absence of uncoordinated donor atoms or protonation sites, makes the $\left[\mathrm{LnL}^{1}\right]^{3+}$ complexes extremely inert. Furthermore, the presence of hydroxyethyl groups in the $\left[\mathrm{LnL}^{1}\right]^{3+}$ complexes results in a sizeable contrast through the CEST mechanism. Thus, this macrocyclic platform represents an attractive alternative to the ubiquitous DOTA derivatives for developing $\mathrm{Ln}^{3+}$ complexes for imaging and therapy applications.

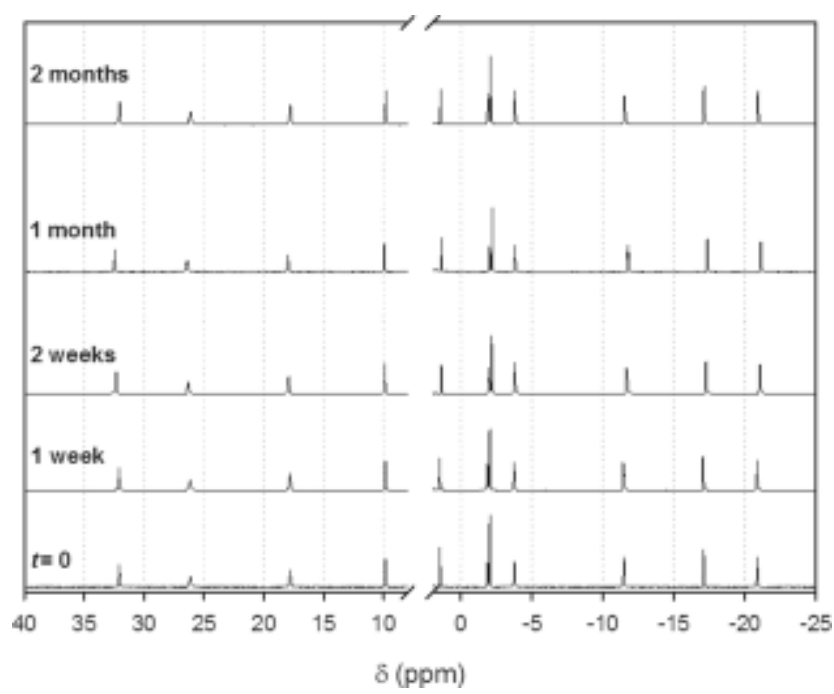

Figure 7. ${ }^{1} \mathrm{H} \mathrm{NMR}$ spectra of the $\left[\mathrm{EuL}^{1}\right]^{3+}$ complex recorded at $25^{\circ} \mathrm{C}$ in $1 \mathrm{~m} \mathrm{HCl}(300 \mathrm{MHz})$ immediately after dissolution of the complex $(t=0)$ and after the indicated time. For better visualization, a break was inserted into the $x$ axis to avoid the huge signal from bulk water.

\section{Experimental Section}

\section{Materials and methods}

All the chemicals used were of the highest available purity and were not purified further. Ethylene oxide and hydrated lanthanide(III) nitrates were obtained from Aldrich. Solvents used were of reagent grade and purified by using the usual methods.

Elemental analyses were performed on a Carlo-Erba EA 1108 microanalyzer. Attenuated total reflection infrared (ATR-FTIR) spectra were recorded on a FP-6100 Jasco spectrometer. UV/Vis spectra were recorded on a PerkinElmer Lambda 900 spectrophotometer by using either quartz cells with a pathlength of either 1.0 $\mathrm{cm}$ or $1 \mathrm{~mm}$. Excitation and emission spectra were recorded on a PerkinElmer LS-50B spectrometer. Luminescence lifetimes were calculated from the monoexponential fitting of the average decay data and are averages of at least 3-5 independent determinations. ESI-MS experiments were performed on an microTOF(focus) mass spectrometer (Bruker Daltonics, Bremen, Germany). Ions were generated by using an ApolloII (ESI) source and ionization was achieved by means of electrospray. ${ }^{1} \mathrm{H}$ NMR spectra were recorded in solutions of $\mathrm{H}_{2} \mathrm{O}$ or $\mathrm{D}_{2} \mathrm{O}$ on a Bruker ARX400 or Bruker Avance 300 NMR spectrometers. CEST spectra were acquired in the latter instrument. 
MRI phantoms were acquired at 25 and $37^{\circ} \mathrm{C}$ on an Agilent VNMRS $11.7 \mathrm{~T}$ vertical wide-bore spectrometer (proton resonance $=500 \mathrm{MHz}$ ) equipped with a millipede MRI probe. Two-dimensional CEST-MRI transversal images were obtained by using a modification of the pulse sequence of fast-spin-echo multi-slice to include a saturation period during the relaxation time (TR). During TR, continuous saturation was applied over $3 \mathrm{~s}$ with a power of $36 \mathrm{~dB}$ (equivalent to $B_{1}=8.2 \mu \mathrm{T}$ ), thus covering a saturation bandwidth of $2000 \mathrm{~Hz}$ (i.e., $4 \mathrm{ppm}$ ). The field of view (FOV) was $50 \times 50 \mathrm{~mm}$, echo train length $(\mathrm{ETL})=8$, echo spacing $(\mathrm{ESP})=4$, $k_{0}=4$, and the effective echo time (TE) $=32 \mathrm{~ms}$. The MRI matrix size was $256 \times 256$ points. To build the CEST curve, 120 MRI images were obtained by varying the saturation frequency offset between -5 and $60 \mathrm{ppm}$ (or 35 and $-25 \mathrm{ppm}$ ) in steps of $250 \mathrm{~Hz}$.

\section{$2,2^{\prime}, 2^{\prime \prime}, 2^{\prime \prime \prime}$-[3,6,10,13-Tetraaza-1,8(2,6)-dipyridinacyclotetradecaphane-3,6,10,13-}

tetrayl]tetrakis(ethan-1-ol) $\left(\mathbf{L}^{\mathbf{1}}\right)$ : A solution of 3,6,10,13-tetraaza-1,8(2,6)-dipyridinacyclotetradecaphane $(1.21 \mathrm{~g}, 3.70 \mathrm{mmol})$ in ethanol $(20 \mathrm{~mL})$ was placed in an ice bath. Ethylene oxide $(39 \mathrm{mmol})$ was bubbled through the solution, and the reaction mixture was stirred for $24 \mathrm{~h}$. A white precipitate was formed, isolated by filtration, and dried to give the desired compound $(1.49 \mathrm{~g}, 79 \%) .{ }^{1} \mathrm{HNMR}\left(400 \mathrm{MHz}, \mathrm{CDCl}_{3}\right.$, $\left.25^{\circ} \mathrm{C}\right): \delta=7.46\left(\mathrm{t},{ }^{3} J_{1,2}=7.63 \mathrm{~Hz}, 2 \mathrm{H} ; \mathrm{H}_{1}\right), 6.96\left(\mathrm{~d},{ }^{3} J_{2,1}=7.64 \mathrm{~Hz}, 4 \mathrm{H} ; \mathrm{H}_{2}\right), 3.49\left(\mathrm{~s}, 8 \mathrm{H} ; \mathrm{H}_{4}\right), 2.59\left(\mathrm{~s}, 8 \mathrm{H} ; \mathrm{H}_{5}\right)$, $2.62\left(\mathrm{t},{ }^{3} J_{6,7}=4.83 \mathrm{~Hz}, 8 \mathrm{H} ; \mathrm{H}_{6}\right), 3.59\left(\mathrm{t},{ }^{3} J_{7,6}=4.81 \mathrm{~Hz}, 8 \mathrm{H} ; \mathrm{H}_{7}\right), 5.25 \mathrm{ppm}\left(\mathrm{s}, 4 \mathrm{H} ; \mathrm{H}_{8}\right) ;{ }^{13} \mathrm{C} \mathrm{NMR}(100.6 \mathrm{MHz}$, $\left.\mathrm{CDCl}_{3}, 25^{\circ} \mathrm{C}\right): \delta=136.6\left(\mathrm{C}_{1}\right), 121.9\left(\mathrm{C}_{2}\right), 158.7\left(\mathrm{C}_{3}\right), 59.2\left(\mathrm{C}_{4}\right), 50.8\left(\mathrm{C}_{5}\right), 56.6\left(\mathrm{C}_{6}\right), 59.1 \mathrm{ppm}\left(\mathrm{C}_{7}\right)$; IR (ATR): $v=1593(\mathrm{~s}), 1447$ (s) $(\mathrm{C} \equiv \mathrm{C})$ and $(\mathrm{C} \equiv \mathrm{N})_{\mathrm{py}}, 2944$ (s), 2919 (s), 2891 (s), $2845 \mathrm{~cm}^{-1}$ (s) (OH); MS $\left(\mathrm{ESI}^{+}\right): m / z 503.3\left[\mathrm{C}_{26} \mathrm{H}_{43} \mathrm{~N}_{6} \mathrm{O}_{4}\right]^{+}$; elemental analysis calcd (\%) for $\mathrm{C}_{26} \mathrm{H}_{42} \mathrm{~N}_{6} \mathrm{O}_{4} \cdot 0.5 \mathrm{H}_{2} \mathrm{O}: \mathrm{C}$ 61.0, $\mathrm{H} \mathrm{8.5,} \mathrm{N}$ 16.4; found: C 61.1, H 8.7, N 16.4.

General procedure for the preparation of the complexes: A solution of $\mathrm{Ln}\left(\mathrm{NO}_{3}\right)_{3} \cdot x \mathrm{H}_{2} \mathrm{O}(0.04 \mathrm{mmol})$ in methanol $(5 \mathrm{~mL})$ was added to a stirred solution of $\mathrm{L}^{1} \cdot 0.5 \mathrm{H}_{2} \mathrm{O}(0.020 \mathrm{~g}, 0.04 \mathrm{mmol})$ in methanol $(10 \mathrm{~mL})$. The solution was allowed to concentrate and crude oils were obtained, which were dissolved in water. Slow concentration of the aqueous solution gave crystalline products, which were isolated by filtration and dried.

$\left[\mathbf{L a L}^{1}\right]\left(\mathrm{NO}_{3}\right)_{3} \cdot 3 \mathrm{H}_{2} \mathbf{O}$ : Yield=0.028 g, $80 \%$; IR (ATR): $v=1602$ (s), 1454 (s) $(\mathrm{C} \equiv \mathrm{C})$ and $(\mathrm{C} \equiv \mathrm{N})_{\mathrm{py}}, 2862$ (m), $2761(\mathrm{~m})(\mathrm{OH}), 1329(\mathrm{~s}), 817(\mathrm{~m}), 827(\mathrm{~m}), 732 \mathrm{~cm}^{-1}(\mathrm{~m})\left(\mathrm{NO}_{3}{ }^{-}\right) ; \mathrm{MS}\left(\mathrm{ESI}^{+}\right): \mathrm{m} / z: 639.2$ $\left[\mathrm{C}_{26} \mathrm{H}_{40} \mathrm{~N}_{6} \mathrm{O}_{4} \mathrm{La}\right]^{+}$; elemental analysis calcd (\%) for $\mathrm{C}_{26} \mathrm{H}_{48} \mathrm{~N}_{9} \mathrm{O}_{16} \mathrm{La}$ : C 35.4, H 5.5, N 14.3; found: C 35.4, $\mathrm{H}$ 5.4, N 14.4 .

$\left[\mathrm{CeL}^{1}\right]\left(\mathrm{NO}_{3}\right)_{3} \cdot 3 \mathrm{H}_{2} \mathbf{O}$ : Yield=0.025 g, $71 \%$; IR (ATR): $v=1603(\mathrm{~s}), 1455(\mathrm{~s})(\mathrm{C} \equiv \mathrm{C})$ and $(\mathrm{C} \equiv \mathrm{N})_{\mathrm{py}}, 2863$ $(\mathrm{m}), 2761(\mathrm{~m})(\mathrm{OH}), 1322(\mathrm{~s}), 816(\mathrm{~m}), 826(\mathrm{~m}), 733 \mathrm{~cm}^{-1}(\mathrm{~m}) \quad\left(\mathrm{NO}_{3}{ }^{-}\right)$; $\mathrm{MS}\left(\mathrm{ESI}^{+}\right): \mathrm{m} / z: 640.2$ $\left[\mathrm{C}_{26} \mathrm{H}_{40} \mathrm{~N}_{6} \mathrm{O}_{4} \mathrm{Ce}\right]^{+}$; elemental analysis calcd (\%) for $\mathrm{C}_{26} \mathrm{H}_{48} \mathrm{~N}_{9} \mathrm{O}_{16} \mathrm{Ce}$ : C 35.4, H 5.5, N 14.3; found: C 35.5, $\mathrm{H}$ 5.4, N 14.4 .

$\left[\mathrm{PrL}^{1}\right]\left(\mathrm{NO}_{3}\right)_{3} \cdot \mathbf{4} \mathbf{H}_{2} \mathbf{O}$ : Yield $=0.022 \mathrm{~g}, 62 \% ;{ }^{1} \mathrm{H}$ NMR (300 MHz, $\left.\mathrm{D}_{2} \mathrm{O}, 25^{\circ} \mathrm{C} . \mathrm{pH} 7.0\right): \delta=9.35\left(2 \mathrm{H} ; \mathrm{H}_{1}\right)$, $10.26\left(4 \mathrm{H} ; \mathrm{H}_{2}\right), 22.88\left(4 \mathrm{H} ; \mathrm{H}_{4 \mathrm{ax}}\right), 16.60\left(4 \mathrm{H} ; \mathrm{H}_{4 \mathrm{eq}}\right), 25.97\left(8 \mathrm{H} ; \mathrm{H}_{5}\right),-18.12\left(4 \mathrm{H} ; \mathrm{H}_{6 \mathrm{ax}}\right), 5.43\left(4 \mathrm{H} ; \mathrm{H}_{6 \mathrm{eq}}\right)$, $1.12\left(4 \mathrm{H} ; \mathrm{H}_{7 \mathrm{ax}}\right),-19.90 \mathrm{ppm}\left(4 \mathrm{H} ; \mathrm{H}_{7 \mathrm{eq}}\right)$; IR (ATR): $v=1606(\mathrm{~s}), 1455(\mathrm{~s})(\mathrm{C} \equiv \mathrm{C})$ and $(\mathrm{C} \equiv \mathrm{N})_{\mathrm{py}}, 2865(\mathrm{~m})$, $2762(\mathrm{~m})(\mathrm{OH}), 1330(\mathrm{~s}), 817(\mathrm{~m}), 826(\mathrm{~m}), 735 \mathrm{~cm}^{-1}(\mathrm{~m})\left(\mathrm{NO}_{3}{ }^{-}\right) ; \mathrm{MS}\left(\mathrm{ESI}^{+}\right): \mathrm{m} / z: 641.2\left[\mathrm{C}_{26} \mathrm{H}_{40} \mathrm{~N}_{6} \mathrm{O}_{4} \mathrm{Pr}\right]^{+}$; elemental analysis calcd (\%) for $\mathrm{C}_{26} \mathrm{H}_{50} \mathrm{~N}_{9} \mathrm{O}_{17}$ Pr: C 34.6, H 5.6, N 14.0; found: C 34.6, H 5.7, N 14.1.

[NdL $\left.{ }^{1}\right]\left(\mathrm{NO}_{3}\right)_{3} \cdot 6 \mathrm{H}_{2} \mathbf{O}$ : Yield=0.024 g, $65 \%$; IR (ATR): $v=1604(\mathrm{~s}), 1455(\mathrm{~s})(\mathrm{C} \equiv \mathrm{C})$ and $(\mathrm{C} \equiv \mathrm{N})_{\mathrm{py}}, 2866$ (m), $2762(\mathrm{~m})(\mathrm{OH}), 1336(\mathrm{~s}), 817(\mathrm{~m}), 827(\mathrm{~m}), 734 \mathrm{~cm}^{-1}(\mathrm{~m})\left(\mathrm{NO}_{3}{ }^{-}\right) ; \mathrm{MS}\left(\mathrm{ESI}^{+}\right): \mathrm{m} / z: 642.2$ $\left[\mathrm{C}_{26} \mathrm{H}_{40} \mathrm{~N}_{6} \mathrm{O}_{4} \mathrm{Nd}\right]^{+}$; elemental analysis calcd (\%) for $\mathrm{C}_{26} \mathrm{H}_{54} \mathrm{~N}_{9} \mathrm{O}_{19} \mathrm{Nd}$ : C 33.2, $\mathrm{H}$ 5.8, N 13.4; found: $\mathrm{C} 33.4, \mathrm{H}$ 5.7, N 13.1.

$\left[\mathrm{SmL}^{1}\right]\left(\mathrm{NO}_{3}\right)_{3} \cdot \mathbf{5} \mathbf{H}_{2} \mathrm{O}$ : Yield=0.026 g, $70 \%$; IR (ATR): $v=1606(\mathrm{~s}), 1455(\mathrm{~s})(\mathrm{C} \equiv \mathrm{C})$ and $(\mathrm{C} \equiv \mathrm{N})_{\mathrm{py}}, 2858$ $(\mathrm{m}), 2761(\mathrm{~m})(\mathrm{OH}), 1330(\mathrm{~s}), 817(\mathrm{~m}), 813(\mathrm{~m}), 738 \mathrm{~cm}^{-1}(\mathrm{~m}) \quad\left(\mathrm{NO}_{3}{ }^{-}\right) ; \quad \mathrm{MS} \quad\left(\mathrm{ESI}^{+}\right): \mathrm{m} / z 652.2$ 
$\left[\mathrm{C}_{26} \mathrm{H}_{40} \mathrm{~N}_{6} \mathrm{O}_{4} \mathrm{Sm}\right]^{+}$; elemental analysis calcd (\%) for $\mathrm{C}_{26} \mathrm{H}_{52} \mathrm{~N}_{9} \mathrm{O}_{18} \mathrm{Sm}$ : C 33.6, H 5.6, N 13.6; found: C 33.7, $\mathrm{H}$ 5.7, N 13.4 .

$\left[\mathbf{E u L}^{1}\right]\left(\mathrm{NO}_{3}\right)_{3} \cdot \mathbf{3} \mathbf{H}_{2} \mathbf{O}: \quad$ Yield=0.018 g, $50 \% ;{ }^{1} \mathrm{H}$ NMR (400 MHz, $\left.\mathrm{D}_{2} \mathrm{O}, 25{ }^{\circ} \mathrm{C} . \mathrm{pH} 7.0\right): \delta=33.58, \quad 18.74$, $10.59,1.45,-1.85,-2.18,-3.51,12.00,-17.43,-21.20 \mathrm{ppm}$; IR (ATR): $v=1605(\mathrm{~s}), 1455$ (s) (C $\equiv \mathrm{C})$ and $(\mathrm{C} \equiv \mathrm{N})_{\mathrm{py}}, 2864(\mathrm{~m}), 2761(\mathrm{~m})(\mathrm{OH}), 1324(\mathrm{~s}), 817(\mathrm{~m}), 826(\mathrm{~m}), 735 \mathrm{~cm}^{-1}(\mathrm{~m})\left(\mathrm{NO}_{3}{ }^{-}\right) ; \mathrm{MS}\left(\mathrm{ESI}^{+}\right): m / z:$ $653.2\left[\mathrm{C}_{26} \mathrm{H}_{40} \mathrm{~N}_{6} \mathrm{O}_{4} \mathrm{Eu}\right]^{+}$; elemental analysis calcd (\%) for $\mathrm{C}_{26} \mathrm{H}_{48} \mathrm{~N}_{9} \mathrm{O}_{16} \mathrm{Eu}$ : C 34.9, H 5.4, N 14.1; found: C 34.8, H 5.4, N 14.1.

$\left[\mathrm{GdL}^{1}\right]\left(\mathrm{NO}_{3}\right)_{3} \cdot 4 \mathrm{H}_{2} \mathrm{O}$ : Yield=0.021 g, $56 \%$; IR (ATR): $v=1605$ (s), $1456(\mathrm{~s})(\mathrm{C} \equiv \mathrm{C})$ and $(\mathrm{C} \equiv \mathrm{N})_{\mathrm{py}}, 2865$ $(\mathrm{m}), 2762(\mathrm{~m})(\mathrm{OH}), 1324(\mathrm{~s}), 817(\mathrm{~m}), 826(\mathrm{~m}), 735 \mathrm{~cm}^{-1}(\mathrm{~m}) \quad\left(\mathrm{NO}_{3}{ }^{-}\right) ; \mathrm{MS}\left(\mathrm{ESI}^{+}\right): \mathrm{m} / z 658.2$ $\left[\mathrm{C}_{26} \mathrm{H}_{40} \mathrm{~N}_{6} \mathrm{O}_{4} \mathrm{Gd}\right]^{+}$; elemental analysis calcd (\%) for $\mathrm{C}_{26} \mathrm{H}_{50} \mathrm{~N}_{9} \mathrm{O}_{17} \mathrm{Gd}$ : C 34.0, H 5.5, N 13.7; found: C 34.1, $\mathrm{H}$ 5.6, N 13.7.

$\left[\mathrm{TbL}^{1}\right]\left(\mathrm{NO}_{3}\right)_{3} \cdot 5 \mathrm{H}_{2} \mathrm{O}$ : Yield=0.026 g, $68 \%$; IR (ATR): $v=1606$ (s), $1456(\mathrm{~s})(\mathrm{C} \equiv \mathrm{C})$ and $(\mathrm{C} \equiv \mathrm{N})_{\mathrm{py}}, 2864$ (m), $2761(\mathrm{~m})(\mathrm{OH}), 1327(\mathrm{~s}), 805(\mathrm{~m}), 742 \mathrm{~cm}^{-1}(\mathrm{~m})\left(\mathrm{NO}_{3}{ }^{-}\right)$; MS $\left(\mathrm{ESI}^{+}\right): \mathrm{m} / z: 659.2\left[\mathrm{C}_{26} \mathrm{H}_{40} \mathrm{~N}_{6} \mathrm{O}_{4} \mathrm{~Tb}\right]^{+}$; elemental analysis calcd (\%) for $\mathrm{C}_{26} \mathrm{H}_{52} \mathrm{~N}_{9} \mathrm{O}_{18} \mathrm{~Tb}$ : C 33.3, H 5.6, N 13.4; found: C 33.2, H 5.8, N 13.5.

$\left[\mathrm{DyL}^{1}\right]\left(\mathrm{NO}_{3}\right)_{3} \cdot \mathbf{4} \mathbf{H}_{2} \mathrm{O}$ : Yield $=0.026 \mathrm{~g}, 71 \%$; IR (ATR): $v=1608$ (s), 1457 (s) $(\mathrm{C} \equiv \mathrm{C})$ and $(\mathrm{C} \equiv \mathrm{N})_{\mathrm{py}}, 2871$ (m), $2764(\mathrm{~m})(\mathrm{OH}), 1336(\mathrm{~s}), 826(\mathrm{~m}), 774 \mathrm{~cm}^{-1}(\mathrm{~m})\left(\mathrm{NO}_{3}{ }^{-}\right)$; MS $\left(\mathrm{ESI}^{+}\right): \mathrm{m} / z: 664.2\left[\mathrm{C}_{26} \mathrm{H}_{40} \mathrm{~N}_{6} \mathrm{O}_{4} \mathrm{Dy}\right]^{+}$; elemental analysis calcd (\%) for $\mathrm{C}_{26} \mathrm{H}_{50} \mathrm{~N}_{9} \mathrm{O}_{17}$ Dy: C 33.8, H 5.5, N 13.7; found: C 33.7, H 5.4, N 13.7.

$\left[\mathrm{HoL}^{1}\right]\left(\mathrm{NO}_{3}\right)_{3} \cdot 6 \mathrm{H}_{2} \mathbf{O}$ : Yield $=0.023 \mathrm{~g}, 60 \%$; IR (ATR): $v=1609$ (s), $1458(\mathrm{~s})(\mathrm{C} \equiv \mathrm{C})$ and $(\mathrm{C} \equiv \mathrm{N})_{\mathrm{py}}, 2873$ (m), $2764(\mathrm{~m})(\mathrm{OH}), 1299(\mathrm{~s}), 825(\mathrm{~m}), 775 \mathrm{~cm}^{-1}(\mathrm{~m})\left(\mathrm{NO}_{3}{ }^{-}\right) ; \mathrm{MS}\left(\mathrm{ESI}^{+}\right): \mathrm{m} / z: 665.2\left[\mathrm{C}_{26} \mathrm{H}_{40} \mathrm{~N}_{6} \mathrm{O}_{4} \mathrm{Ho}\right]^{+}$; elemental analysis calcd (\%) for $\mathrm{C}_{26} \mathrm{H}_{54} \mathrm{~N}_{9} \mathrm{O}_{19} \mathrm{Ho}$ : C 32.4, H 5.7, N 13.1; found: C 32.0, H 5.5, N 13.3.

$\left[\mathrm{ErL}^{1}\right]\left(\mathrm{NO}_{3}\right)_{3} \cdot 6 \mathrm{H}_{2} \mathbf{O}$ : Yield=0.024 g, $62 \%$; IR (ATR): $v=1608$ (s), 1458 (s) $(\mathrm{C} \equiv \mathrm{C})$ and $(\mathrm{C} \equiv \mathrm{N})_{\mathrm{py}}, 2873$ (m), $2762(\mathrm{~m})(\mathrm{OH}), 1301(\mathrm{~s}), 825(\mathrm{~m}), 746 \mathrm{~cm}^{-1}(\mathrm{~m})\left(\mathrm{NO}_{3}{ }^{-}\right)$; $\mathrm{MS}\left(\mathrm{ESI}^{+}\right): \mathrm{m} / z: 666.2\left[\mathrm{C}_{26} \mathrm{H}_{40} \mathrm{~N}_{6} \mathrm{O}_{4} \mathrm{Er}\right]^{+}$; elemental analysis calcd (\%) for $\mathrm{C}_{26} \mathrm{H}_{54} \mathrm{~N}_{9} \mathrm{O}_{19} \mathrm{Er}$ : C 32.4, H 5.7, N 13.1; found: C 32.3, H 5.9, N 13.1.

$\left[\mathrm{TmL}^{1}\right]\left(\mathrm{NO}_{3}\right)_{3} \cdot \mathbf{6} \mathrm{H}_{2} \mathbf{O}$ : Yield=0.027 g, $70 \%$; IR (ATR): $v=1608(\mathrm{~s}), 1458(\mathrm{~s})(\mathrm{C} \equiv \mathrm{C})$ and $(\mathrm{C} \equiv \mathrm{N})_{\mathrm{py}}, 2871$ (m), $2762(\mathrm{~m})(\mathrm{OH}), 1307(\mathrm{~s}), 825(\mathrm{~m}), 746 \mathrm{~cm}^{-1}(\mathrm{~m})\left(\mathrm{NO}_{3}{ }^{-}\right) ; \mathrm{MS}\left(\mathrm{ESI}^{+}\right): \mathrm{m} / z: 669.3\left[\mathrm{C}_{26} \mathrm{H}_{40} \mathrm{~N}_{6} \mathrm{O}_{4} \mathrm{Tm}\right]^{+}$; elemental analysis calcd (\%) for $\mathrm{C}_{26} \mathrm{H}_{54} \mathrm{~N}_{9} \mathrm{O}_{19} \mathrm{Tm}$ : C 32.3, H 5.6, N 13.1; found: C 32.2, H 5.4, N 13.4.

[Y $\mathbf{Y b L}^{1}{ }^{1}\left(\mathrm{NO}_{3}\right)_{3} \cdot 6 \mathbf{H}_{2} \mathbf{O}$ : Yield=0.022 g, $57 \%$; ${ }^{1} \mathrm{H}$ NMR $\left(300 \mathrm{MHz}, \mathrm{D}_{2} \mathrm{O}, 25{ }^{\circ} \mathrm{C}, \mathrm{pH} 7.0\right): \delta=-4.69\left(2 \mathrm{H} ; \mathrm{H}_{1}\right)$, $-9.43\left(4 \mathrm{H} ; \mathrm{H}_{2}\right),-33.84\left(4 \mathrm{H} ; \mathrm{H}_{4 \mathrm{ax}}\right),-19.77\left(4 \mathrm{H} ; \mathrm{H}_{4 \mathrm{eq}}\right),-9.05\left(4 \mathrm{H} ; \mathrm{H}_{5 \mathrm{ax}}\right),-12.79\left(4 \mathrm{H} ; \mathrm{H}_{5 \mathrm{eq}}\right) 41.87(4 \mathrm{H}$; $\left.\mathrm{H}_{6 \mathrm{ax}}\right), 14.11\left(4 \mathrm{H} ; \mathrm{H}_{6 \mathrm{eq}}\right), 31.65\left(4 \mathrm{H} ; \mathrm{H}_{7 \mathrm{ax}}\right), 70.34 \mathrm{ppm}\left(4 \mathrm{H} ; \mathrm{H}_{7 \mathrm{eq}}\right)$; IR (ATR): v=1606 (s), 1457 (s) (C $\left.\equiv \mathrm{C}\right)$ and $(\mathrm{C} \equiv \mathrm{N})_{\mathrm{py}}, 2869(\mathrm{~m}), 2763(\mathrm{~m})(\mathrm{OH}), 1330(\mathrm{~s}), 827(\mathrm{~m}), 737 \mathrm{~cm}^{-1}(\mathrm{~m})\left(\mathrm{NO}_{3}{ }^{-}\right) ; \mathrm{MS}\left(\mathrm{ESI}^{+}\right): \mathrm{m} / z: 674.3$ $\left[\mathrm{C}_{26} \mathrm{H}_{40} \mathrm{~N}_{6} \mathrm{O}_{4} \mathrm{Yb}\right]^{+}$; elemental analysis calcd (\%) for $\mathrm{C}_{26} \mathrm{H}_{54} \mathrm{~N}_{9} \mathrm{O}_{19} \mathrm{Yb}$ : C 32.2, H 5.6, N 13.0; found: C 32.0, $\mathrm{H}$ 5.4, N 13.3.

$\left[\mathrm{LuL}^{1}\right]\left(\mathrm{NO}_{3}\right)_{3} \cdot \mathbf{6} \mathbf{H}_{2} \mathbf{O}$ : Yield $=0.028 \mathrm{~g}, 72 \% ;{ }^{1} \mathrm{H} \mathrm{NMR}\left(400 \mathrm{MHz}, \mathrm{CDCl}_{3}, 25^{\circ} \mathrm{C}\right): \delta=7.97\left(\mathrm{t},{ }^{3} J_{1,2}=7.79 \mathrm{~Hz}\right.$, $\left.2 \mathrm{H} ; \mathrm{H}_{1}\right), 7.49\left(\mathrm{~d},{ }^{3} J_{2,1}=7.87 \mathrm{~Hz}, 4 \mathrm{H} ; \mathrm{H}_{2}\right), 3.88\left(\mathrm{~m}, 4 \mathrm{H} ; \mathrm{H}_{4 \mathrm{ax}}\right), 4.63\left(\mathrm{~d},{ }^{2} J_{4 \mathrm{eq}, 4 \mathrm{ax}}=16.35 \mathrm{~Hz}, 4 \mathrm{H} ; \mathrm{H}_{4 \mathrm{eq}}\right), 2.57$ (m, $\left.4 \mathrm{H} ; \mathrm{H}_{5 \mathrm{ax}}\right), 3.55$ (m, $\left.4 \mathrm{H} ; \mathrm{H}_{5 \mathrm{eq}}\right), 3.17\left(\mathrm{~m}, 4 \mathrm{H} ; \mathrm{H}_{6 \mathrm{ax}}\right), 2.63$ (m, $\left.4 \mathrm{H} ; \mathrm{H}_{6 \mathrm{eq}}\right), 4.15$ (m, $\left.4 \mathrm{H} ; \mathrm{H}_{7 \mathrm{ax}}\right), 3.86 \mathrm{ppm}(\mathrm{m}$, $\left.4 \mathrm{H} ; \mathrm{H}_{7 \mathrm{eq}}\right) ;{ }^{13} \mathrm{C}$ NMR $\left(100.6 \mathrm{MHz}, \mathrm{D}_{2} \mathrm{O}, \mathrm{pH} 7.0,25^{\circ} \mathrm{C}\right): \delta=140.8\left(\mathrm{C}_{1}\right), 123.7\left(\mathrm{C}_{2}\right), 157.3\left(\mathrm{C}_{3}\right), 59.5\left(\mathrm{C}_{4}\right), 49.3$ $\left(\mathrm{C}_{5}\right), 52.2\left(\mathrm{C}_{6}\right), 57.7 \mathrm{ppm}\left(\mathrm{C}_{7}\right)$; IR (ATR): $v=1606(\mathrm{~s}), 1457(\mathrm{~s})(\mathrm{C} \equiv \mathrm{C})$ and $(\mathrm{C} \equiv \mathrm{N})_{\mathrm{py}}, 2869(\mathrm{~m}), 2763(\mathrm{~m})$ $(\mathrm{OH}), 1330(\mathrm{~s}), 826(\mathrm{~m}), 737 \mathrm{~cm}^{-1}(\mathrm{~m})\left(\mathrm{NO}_{3}{ }^{-}\right)$; $\mathrm{MS}\left(\mathrm{ESI}^{+}\right): \mathrm{m} / z: 675.3\left[\mathrm{C}_{26} \mathrm{H}_{40} \mathrm{~N}_{6} \mathrm{O}_{4} \mathrm{Lu}\right]^{+}$; elemental analysis calcd (\%) for $\mathrm{C}_{26} \mathrm{H}_{54} \mathrm{~N}_{9} \mathrm{O}_{19} \mathrm{Lu}$ : C 32.1, H 5.6, N 13.0; found: C 32.3, H 5.8, N 13.3.

Crystal-structure determinations: Single-crystal X-ray diffraction measurements were performed on Bruker Smart-CCD-1000 ([LaL $\left.{ }^{1}\right]\left(\mathrm{NO}_{3}\right)_{3} \cdot 2 \mathrm{H}_{2} \mathrm{O},\left[\mathrm{NdL}^{1}\right]\left(\mathrm{NO}_{3}\right)_{3} \cdot 6 \mathrm{H}_{2} \mathrm{O}$, and $\left.\left[\mathrm{SmL}^{1}\right]\left(\mathrm{NO}_{3}\right)_{3} \cdot 5 \mathrm{H}_{2} \mathrm{O}\right)$ or Bruker Smart-CCD- $6000\left(\left[\mathrm{PrL}^{1}\right]\left(\mathrm{NO}_{3}\right)_{3} \cdot 4 \mathrm{H}_{2} \mathrm{O}\right.$, $\left[\mathrm{YbL}^{1}\right]\left(\mathrm{NO}_{3}\right)_{3} \cdot 6 \mathrm{H}_{2} \mathrm{O}$, and $\left.\left[\mathrm{LuL}^{1}\right]\left(\mathrm{NO}_{3}\right)_{3} \cdot 6 \mathrm{H}_{2} \mathrm{O}\right)$ diffractometers. 
Graphite monochromated $\mathrm{Mo}_{\mathrm{K} \alpha}$ was used on the Bruker Smart-CCD-1000 diffractometer and $\mathrm{Cu}_{\mathrm{K} \alpha}$ on the Bruker Smart-CCD 6000 diffractometer. The data were recorded at $298 \mathrm{~K}$ for $\left[\mathrm{LaL}^{1}\right]\left(\mathrm{NO}_{3}\right)_{3} \cdot 2 \mathrm{H}_{2} \mathrm{O}$, $\left[\mathrm{PrL}^{1}\right]\left(\mathrm{NO}_{3}\right)_{3} \cdot 4 \mathrm{H}_{2} \mathrm{O},\left[\mathrm{NdL}^{1}\right]\left(\mathrm{NO}_{3}\right)_{3} \cdot 6 \mathrm{H}_{2} \mathrm{O},\left[\mathrm{SmL}^{1}\right]\left(\mathrm{NO}_{3}\right)_{3} \cdot 5 \mathrm{H}_{2} \mathrm{O}$, and $\left[\mathrm{LuL}^{1}\right]\left(\mathrm{NO}_{3}\right)_{3} \cdot 6 \mathrm{H}_{2} \mathrm{O}$ and at $100 \mathrm{~K}$ for $\left[\mathrm{YbL}^{1}\right]\left(\mathrm{NO}_{3}\right)_{3} \cdot 6 \mathrm{H}_{2} \mathrm{O}$. All the data were corrected by applying Lorentz and polarization effects. Empirical absorption corrections were also applied. ${ }^{[40]}$ Complex scattering factors were taken from the program package SHELX-97. ${ }^{[41]}$ The structures were solved by using direct methods with SIR-92, ${ }^{[42]}$ which revealed the position of all the non-hydrogen atoms. All the structures were refined on $F^{2}$ by using a full-matrix leastsquares procedure with anisotropic-displacement parameters for all non-hydrogen atoms. The hydrogen atoms of the carbon atoms were located in their calculated positions and refined by using a riding model. The hydrogen atoms of the hydroxyethyl groups were located on a difference-Fourier map and refined isotropically. Molecular graphics were generated by using USCF Chimera (version 1.8). ${ }^{[43]}$ and WebLAB ViewerPro 4.0. CCDC 1414265-1414270 contain the supplementary crystallographic data for this paper. These data are provided free of charge by The Cambridge Crystallographic Data Centre.

Computational details: All the calculations were carried out by using the Gaussian 09 package (Revision D.01). ${ }^{[44]}$ Full-geometry optimizations of the $\left[\mathrm{PrL}^{1}\right]^{3+}$ and $\left[\mathrm{YbL}^{1}\right]^{3+}$ complexes were performed in aqueous solution by employing DFT within the hybrid meta-generalized gradient approximation (hybrid meta-GGA) with the TPSSh exchange-correlation functional. ${ }^{[45]}$ The large-core quasirelativistic effective core potential (LCRECP) developed by Dolg and co-workers and the associated [5 s4p3d]-GTO valence-basis set was employed for the lanthanides, ${ }^{[46]}$ whereas the ligand atoms were described by using the standard $6-31 \mathrm{G}(\mathrm{d}, \mathrm{p})$ basis set. The stationary points found on the potential-energy surfaces as a result of geometry optimizations were tested to represent energy minima rather than saddle points by using frequency analysis. Solvent effects were included by using the integral-equation formalism variant of the polarizable continuum model (IEFPCM). ${ }^{[4]}$

\section{Acknowledgements}

L.V. and P.P.-L. thank the Ministerio de Ciencia e Innovación, Plan Nacional de I+D+i (CTQ2011-24487) for financial support. M.R.-F., D.E.-G., and C.P.-I. thank the Ministerio de Economía y Competitividad (CTQ2013-43243-P) for generous financial support. The authors are indebted to the Centro de Supercomputación of Galicia (CESGA) for providing computer facilities and to CACTI (Universidade de Vigo) for X-ray measurements. The authors thank Jorge Otero (SAI, Universidade da Coruña) for his assistance with the acquisition of the CEST spectra.

[1] A. E. Merbach, L. Helm, E. Tûth, The Chemistry of Contrast Agents in Medical Magnetic Resonance Imaging, 2nd ed., Wiley, New York, 2013.

[2] a) E. Terreno, D. Delli Castelli, A. Viale, S. Aime, Chem. Rev. 2010, 110, 3019-3042; b) V. Kub $\square c^{`}$ ek, E. Toth, Adv. Inorg. Chem. 2009, 61, 63-129; c) S. Aime, D. Delli Castelli, S. Geninatti Crich, E. Gianolio, E. Terreno, Acc. Chem. Res. 2009, 42, 822-831; d) A. Datta, K. N. Raymond, Acc. Chem. Res. 2009, 42, 938-947; e) E. J. Werner, A. Datta, C. J. Jocher, K. N. Raymond, Angew. Chem. Int. Ed. 2008, 47, 85688580; Angew. Chem. 2008, 120, 8696-8709.

[3] a) S. Aime, S. Geninatti Crich, E. Gianolio, G. B. Giovenzana, L. Tei, E. Terreno, Coord. Chem. Rev. 2006, 250, 1562-1579; b) E. Terreno, D. Delli Castelli, S. Aime, Contrast Media Mol. Imaging 2010, 5, 78 98. 
[4] a) E. Vinogradov, A. D. Sherry, R. E. Lenkinski, J. Magn. Reson. 2013, 229, 155-172; b) P. C. M. van Zijl, N. N. Yadav, Magn. Reson. Med. 2011, 65, 927-948; c) X. Yang, N. N. Yadav, X. Song, S. R. Banerjee, H. Edelman, I. Minn, P. C. M. van Zijl, M. G. Pomper, M. T. McMahon, Chem. Eur. J. 2014, 20, 15824-15832.

[5] a) S. J. Dorazio, J. R. Morrow, Eur. J. Inorg. Chem. 2012, 2006-2014; b) P. B. Tsitovich, P. J. Burns, A. M. McKay, J. R. Morrow, J. Inorg. Biochem. 2014, 133, 143-154.

[6] a) S. J. Ratnakar, M. Woods, A. J. M. Lubag, Z. Kovacs, A. D. Sherry, J. Am. Chem. Soc. 2008, 130, 67; b) S. J. Ratnakar, T. C. Soesbe, L. L. Lumata, Q. N. Do, S. Viswanathan, C.-Y. Lin, A. D. Sherry, Z. Kovacs, J. Am. Chem. Soc. 2013, 135, 14904-14907.

[7] S. J. Dorazio, A. O. Olatunde, P. B. Tsitovich, J. R. Morrow, J. Biol. Inorg. Chem. 2014, 19, 191-205.

[8] a) A. X. Li, M. Suchy, C. Li, J. S. Gati, S. Meakin, R. H. E. Hudson, R. S Menona, R. Bartha, Magn. Reson. Med. 2011, 66, 67-72; b) N. McVicar, A. X. Li, M. Suchy, R. H. E. Hudson, R. S. Menon, R. Bartha, Magn. Reson. Med. 2013, 70, 1016-1025.

[9] a) S. Zhang, L. Michaudet, S. Burgess, A. D. Sherry, Angew. Chem. Int. Ed. 2002, 41, 1919-1921; Angew. Chem. 2002, 114, 1999-2001; b) S. Viswanathan, S. J. Ratnakar, K. N. Green, Z. Kovacs, L. M. De Leon-Rodriguez, A. D. Sherry, Angew. Chem. Int. Ed. 2009, 48, 9330-9333; Angew. Chem. 2009, 121, 9494-9497.

[10] a) T. Chauvin, P. Durand, M. Bernier, H. Meudal, B.-T. Doan, F. Noury, B. Badet, J.-C. Beloeil, E. Toth, Angew. Chem. Int. Ed. 2008, 47, 4370-4372; Angew. Chem. 2008, 120, 4442-4444; b) G. Liu, Y. Li, M. D. Pagel, Magn. Reson. Med. 2007, 58, 1249-1256.

[11] a) S. Zhang, P. Winter, K. Wu, A. D. Sherry, J. Am. Chem. Soc. 2001, 123, 1517-1518; b) Y. Huang, D. Coman, M. M. Ali, F. Hyder, Contrast Media Mol. Imaging 2015, 10, 51-58; c) S. Zhang, M. Merritt, D. E. Woessner, R. E. Lenkinski, A. D. Sherry, Acc. Chem. Res. 2003, 36, 783-790; d) K. N. Green, S. Viswanathan, F. A. Rojas-Quijano, Z. Kovacs, A. D. Sherry, Inorg. Chem. 2011, 50, 1648-1655; e) S. Zhang, K. Wu, M. C. Biewer, A. D. Sherry, Inorg. Chem. 2001, 40, 4284-4290.

[12] C.-H. Huang, J. R. Morrow, J. Am. Chem. Soc. 2009, 131, 4206-4207.

[13] M. Woods, D. E. Woessner, P. Zhao, A. Pasha, M.-Y. Yang, C.-H. Huang, O. Vasalitiy, J. R. Morrow, A. D. Sherry, J. Am. Chem. Soc. 2006, 128, 10155-10162.

[14] a) C.-H. Huang, J. R. Morrow, Inorg. Chem. 2009, 48, 7237-7243; b) J. Hammell, L. Buttarazzi, C.-H. Huang, J. R. Morrow, Inorg. Chem. 2011, 50, 4857-4867.

[15] R. Filipi, K. Nesmerak, M. Rucki, Z. Roth, I. Hanzlikova, M. Tichy, Chem. Listy 2007, 101, 793-798.

[16] a) G. Ferrauto, D. Delli Castelli, E. Terreno, S. Aime, Magn. Reson. Med. 2013, 69, 1703-1711; b) A. Pasha, G. Tirsû, E. T. Benyû, E. Brìcher, A. D. Sherry, Eur. J. Inorg. Chem. 2007, 4340-4349; c) Z. Baranyai, Z. Palinkas, F. Uggeri, A. Maiocchi, S. Aime, E. Brìcher, Chem. Eur. J. 2012, 18, 16426-16435.

[17] S. Viswanathan, Z. Kovacs, K. N. Green, S. J. Ratnakar, A. D. Sherry, Chem. Rev. 2010, 110, 29603018.

[18] G. L. Rothermel Jr., L. Miao, A. L. Hill, S. C. Jackels, Inorg. Chem. 1992, 31, 4854-4859.

[19] L. Valencia, J. Mart† nez, A. Mac $\dagger$ as, R. Bastida, R. A. Carvalho, C. F. G. C. Geraldes, Inorg. Chem. 2002, 41, 5300-5312. 
[20] S. W. A. Bligh, N. Choi, C. F. G. C. Geraldes, S. Knoke, M. McPartlin, M. J. Sanganee, T. M. Woodroffe, J. Chem. Soc. Dalton Trans. 1997, 4119-4125.

[21] M. del C. Fern, ndez-Fern, ndez, R. Bastida, A. Macias, P. Perez-Lourido, C. Platas-Iglesias, L. Valencia, Inorg. Chem. 2006, 45, 4484-4496.

[22] C. NfflÇez, R. Bastida, A. Macias, M. Mato-Iglesias, C. Platas-Iglesias, L. Valencia, Dalton Trans. 2008, 3841-3850.

[23] M. Seitz, A. G. Oliver, K. N. Raymond, J. Am. Chem. Soc. 2007, 129, 11153-11160.

[24] G. Castro, R. Bastida, A. Macias, P. Perez-Lourido, C. Platas-Iglesias, L. Valencia, Inorg. Chem. 2015, $54,1671-1683$.

[25] M. Latva, H. Takalo, V.-M. Mukkala, C. Matachescu, J. C. Rodriguez-Ubis, J. Kankare, J. Lumin. 1997, $75,149-169$.

[26] A. Beeby, I. M. Clarkson, R. S. Dickins, S. Faulkner, D. Parker, L. Royle, A. S. de Sousa, J. A. G. Williams, M. Woods, J. Chem. Soc. Perkin Trans. 2 1999, 493-503.

[27] a) J. A. Peters, J. Huskens, D. J. Raber, Prog. Nucl. Magn. Reson. Spectrosc. 1996, 28, 283-350; b) I. Bertini, C. Luchinat, G. Parigi, Prog. Nucl. Magn. Reson. Spectrosc. 2002, 40, 249-273.

[28] J. H. Forsberg, R. M. Delaney, Q. Zhao, G. Harakas, R. Chandran, Inorg. Chem. 1995, 34, 3705-3715.

[29] A. Rodr† guez-Rodr† guez, D. Esteban-Gomez, R. Tripier, G. Tircso, Z. Garda, I. Toth, A. de Blas, T. Rodriguez-Blas, C. Platas-Iglesias, J. Am. Chem. Soc. 2014, 136, 17954-17957.

[30] a) C. Doffek, N. Alzakhem, C. Bischof, J. Wahsner, T. Gìden-Silber, J. Lìgger, C. Platas-Iglesias, M. Seitz, J. Am. Chem. Soc. 2012, 134, 16413-16423; b) T. Lui, A. Nonat, M. Beyler, M. Regueiro-Figueroa, K. N. Nono, O. Jeannin, F. Camerel, F. Debaene, S. Cianferani-Sanglier, R. Tripier, C. Platas-Iglesias, L. J. Charbonniere, Angew. Chem. Int. Ed. 2014, 53, 7259-7263; Angew. Chem. 2014, 126, 7387-7391.

[31] a) M. R. Willcott, R. E. Lenkinski, R. E. Davis, J. Am. Chem. Soc. 1972, 94, 1742-1744; b) R. E. Davis, M. R. Willcott, J. Am. Chem. Soc. 1972, 94, 1744-1745.

[32] a) J. Lisowski, J. L. Sessler, V. Lynch, T. D. Mody, J. Am. Chem. Soc. 1995, 117, 2273-2285; b) J. Vipond, M. Woods, P. Zhao, G. Tircso, J. Ren, S. G. Bott, D. Ogrin, G. E. Kiefer, Z. Kovacs, A. D. Sherry, Inorg. Chem. 2007, 46, 2584-2595.

[33] a) M. Regueiro-Figueroa, J. L. Barriada, A. Pallier, D. Esteban-Gomez, A. de Blas, T. Rodriguez-Blas, E. Toth, C. Platas-Iglesias, Inorg. Chem. 2015, 54, 4940-4952; b) A. Roca-Sabio, M. Mato-Iglesias, D. Esteban-Gomez, E. Toth, A. de Blas, C. Platas-Iglesias, T. Rodriguez-Blas, J. Am. Chem. Soc. 2009, 131, $3331-3341$.

[34] B. Bleaney, J. Magn. Reson. 1972, 8, 91-100.

[35] a) A. A. Pinkerton, M. Rossier, S. Spiliadis, J. Magn. Reson. 1985, 64, 420-425; b) R. M. Golding, P. Pyykkç, Mol. Phys. 1973, 26, 1389-1396.

[36] a) W. T. Dixon, J. Ren, A. J. M. Lubag, J. Ratnakar, E. Vinogradov, I. Hancu, R. E. Lenkinski, A. D. Sherry, Magn. Reson. Med. 2010, 63, 625-632; b) O. M. Evbuomwan, J. Lee, M. Woods, A. D. Sherry, Inorg. Chem. 2014, 53, 10012-10014. 
[37] S. Laurent, L. Vander Elst, C. Henoumont, R. N. Muller, Contrast Media Mol. Imaging 2010, 5, 305308.

[38] M. Polasek, P. Caravan, Inorg. Chem. 2013, 52, 4084-4096.

[39] E. Toth, E. Brucher, I. Lazar, I. Toth, Inorg. Chem. 1994, 33, 4070-4076.

[40] G. M. Sheldrick, Sadabs. Program for Empirical Absoption Correction of Area Detector Data. University of Gçtingen, Germany, 1996.

[41] G. M. Sheldrick, SHELX-97, An integrated system for solving and refining crystal structures from diffraction data, University of Gçttingen, Germany, 1997.

[42] A. Altomare, G. Cascarano, C. Giacovazzo, A. Gualardi, J. Appl. Crystallogr. 1993, 26, 343-350.

[43] E. F. Pettersen, T. D. Goddard, C. C. Huang, G. S. Couch, D. M. Greenblatt, E. C. Meng, T. E. Ferrin, J. Comput. Chem. 2004, 25, 1605-1612.

[44] Gaussian 09, Revision D.01, M. J. Frisch, G. W. Trucks, H. B. Schlegel, G. E. Scuseria, M. A. Robb, J. R. Cheeseman, G. Scalmani, V. Barone, B. Mennucci, G. A. Petersson, H. Nakatsuji, M. Caricato, X. Li, H. P. Hratchian, A. F. Izmaylov, J. Bloino, G. Zheng, J. L. Sonnenberg, M. Hada, M. Ehara, K. Toyota, R. Fukuda, J. Hasegawa, M. Ishida, T. Nakajima, Y. Honda, O. Kitao, H. Nakai, T. Vreven, J. A. Montgomery, Jr., J. E. Peralta, F. Ogliaro, M. Bearpark, J. J. Heyd, E. Brothers, K. N. Kudin, V. N. Staroverov, R. Kobayashi, J. Normand, K. Raghavachari, A. Rendell, J. C. Burant, S. S. Iyengar, J. Tomasi, M. Cossi, N. Rega, J. M. Millam, M. Klene, J. E. Knox, J. B. Cross, V. Bakken, C. Adamo, J. Jaramillo, R. Gomperts, R. E. Stratmann, O. Yazyev, A. J. Austin, R. Cammi, C. Pomelli, J. W. Ochterski, R. L. Martin, K. Morokuma, V. G. Zakrzewski, G. A. Voth, P. Salvador, J. J. Dannenberg, S. Dapprich, A. D. Daniels, @. Farkas, J. B. Foresman, J. V. Ortiz, J. Cioslowski, D. J. Fox, Gaussian, Inc. Wallingford CT, 2009.

[45] J. M. Tao, J. P. Perdew, V. N. Staroverov, G. E. Scuseria, Phys. Rev. Lett. 2003, 91, 146401.

[46] M. Dolg, H. Stoll, A. Savin, H. Preuss, Theor. Chim. Acta 1989, 75, 173-194.

[47] J. Tomasi, B. Mennucci, R. Cammi, Chem. Rev. 2005, 105, 2999-3093. 